\title{
Transmisibilidad del derecho a la reparación del daño moral
}

\author{
Germán Antonio Orozco Gadea \\ Profesor asociado Universidad Centroamericana, Nicaragua \\ german@ns.uca.edu.ni
}

Fecha de recibido: 15 de noviembre 2013 / Fecha de aprobación: 04 de marzo 2014

\section{Resumen}

La doctrina partidaria de la transmisión del Derecho a la reparación del daño moral ha enfrentado una dura polémica. Dentro de esta controversia encontramos tres posturas: una plantea que el derecho a la reparación del daño moral se extinguiría con el fallecimiento de la víctima; la otra, establece que los familiares del interfecto están legitimados iure hereditario para solicitar la reparación, porque dicho derecho es un crédito que ingresa en el patrimonio de la víctima y luego lo transmite a sus herederos; por último, para un tercera postura, las personas pueden exigir la reparación de estos perjuicios por vía iure proprio, porque han tenido estrechos vínculos afectivos con el interfecto y el dolor y sufrimiento que padecen por su muerte merece ser compensado. Sin embargo, todos estos autores coinciden en admitir la transmisión del Derecho a la reparación del daño moral, cuando la víctima había incoado la demanda y muere antes de ser indemnizada. Dentro de este contexto, no podemos soslayar, el tema de la enajenación del derecho a la reparación de esta clase de daños por actos entre vivos. Según nuestro criterio, es muy difícil admitir ésta última clase de enajenación porque se distorsiona la función que cumple la reparación del daño moral.

\section{Palabras clave}

Daño moral / víctima / reparación / familiares / transmisión 


\section{Dereche}

\section{Abstract}

The doctrine in favor of transferring the Law to reparation of non economic loss has faced controversy. There are three positions in this controversy. One of them suggests that the right to reparation of non pecuniary loss would become extinct with the death of the victim. Another position establishes that the murdered victim's relatives are entitled to iure hereditario in order to request repair, because that right is a credit that goes in the victim's state and then it is transferred to his heirs. Finally, for a third position, people can demand repair of these damages via iure proprio, because they have had close emotional ties with the murdered victim and the pain and suffering due to their death deserves compensation. However, all these authors agree to support the transmission of the Law to compensate for personal injury when the victim had initiated the demand and dies before compensation. In this context, we cannot avoid the issue of the transfer of the right to reparation of this kind of damage due to the actions of the living. According to our judgment, it is very difficult to admit this last kind of alienation because it distorts the role fulfilled by the reparation of moral damage.

\section{Key words}

Non economic loss / victim / repairing / relatives / transfer

\section{Tabla de contenido}

I. Introducción. II. Controversia en cuanto a la transmisión de la reparación de esta clase de menoscabos. III. Prohibición de la transmisión del derecho a la reparación del daño moral a los acreedores. IV. Legitimación iure proprio y/o iure hereditario. 1. Consecuencias prácticas. 2. Evolución jurisprudencial adoptada por cada una de las Salas civiles y penales del Tribunal Supremo español. 3. Antagonismo doctrinal. V.Transmisibilidad del derecho a la reparación del daño moral por acto entre vivos (inter vivos). VI. Conclusiones. VII. Referencias bibliográficas. VIII. Abreviaturas. 


\section{Introducción}

En el intrincado ámbito del daño moral, especial atención merece el tema de su transmisibilidad; es decir, hacemos referencia a aquellas situaciones en las que víctima directa fallece. En estos casos, se discute si otras personas, como, por ejemplo, los familiares tendrían o no derecho a exigir una suma de dinero en concepto de compensación por daño moral; y, en el supuesto de que se admita su derecho, aún los doctrinarios no se ponen de acuerdo bajo qué concepto obtendrían esa compensación pecuniaria: si como herederos del perjudicado directo (iure hereditario) o como perjudicados directos (iure proprio). Dilucidar esta controversia desborda una bizantina polémica doctrinal, pues tiene importantes efectos prácticos determinar el rubro bajo el cual se obtiene el dinero; por ejemplo, si concebimos que el dinero se paga a los herederos, solo los familiares del interfecto tendrían derecho a obtenerlo (iure hereditario). Por el contrario, si adscribimos la compensación en metálico en razón del perjuicio personal (iure propio) como el sufrimiento o dolor que se experimenta por la muerte de un ser humano, se ensancha la categoría de personas que podrían demandar la responsabilidad del agente dañoso; así, podría abarcar ciertos sujetos que sin ostentar la condición de familiares demuestren una real y fehaciente consternación por el deceso de su ser querido, imaginemos el supuesto de una prometida traumada por la muerte de su novio o los padres de crianza por la muerte de aquélla persona que trataron toda la vida como un hijo o hija.

Antes de continuar con esta investigación, es conveniente intentar proporcionar una definición de esta clase de menoscabos; en este sentido, podemos decir que "El daño moral es todo perjuicio extrapatrimonial, que afecta intereses jurídicos que recaen sobre bienes no patrimoniales, que por carecer de equivalencia pecuniaria se reparan a través de una compensación satisfactoria monetaria" (OrOzco Gadea, 2006, p. 443).

La reparación del daño moral en la legislación nicaragüense puede tener cabida en el área contractual (art 1860 C) y en el ámbito extracontractual (art. 2509 C). Además, mediante la Ley 157/1993 Ley de interpretación auténtica de los artículos 2509, 1837, 1838, 1865, y 3106 del Código civil y el numeral 2) del artículo 1123 del Código de procedimiento civil, publicada en E1 Nuevo Diario del 26 de Marzo de 1993, se reafirma esta consideración mediante el art. 1 párrafo $1^{\circ}$ que reza así:

La responsabilidad civil por daños y perjuicios a que se refiere el Arto. 2509 C. y siguientes (Título VIII, Capítulo Único sobre Delitos y Cuasidelitos) es en su 
totalidad, sin exclusión, comprendiendo tanto daños materiales como morales. No existe provisión alguna de la Ley que las limite a daños estrictamente materiales y que excluya los daños morales.

\section{Consideramos que las razones esgrimidas para admitir la reparación del daño moral en la responsabilidad aquiliana, son también viables en la sede contrac- tual. ${ }^{1}$ En consecuencia, en ambas ramas de la responsabilidad civil, cabe analizar}

1 Las razones formuladas en pro de la admisión de la reparación de los daños morales han sido formuladas para contrarrestar la doctrina contraria al resarcimiento de esta clase de menoscabos; así, por ejemplo, se aduce que no se deben reparar por la imposibilidad de demostrar jurídicamente la existencia del agravio moral; así, Los detractores de la reparación del daño moral argumentan que siendo una de las particularidades esenciales de estos menoscabos el afectar los sentimientos más íntimos del ser humano, la demostración de los mismos se tornaría en un imposible. Ciertamente, para el juzgador, escudriñar las sensaciones más sublimes de una persona es extremadamente difícil o prácticamente imposible. Cualquier persona podría aparentar padecer un daño de estas características con la oscura intención de obtener un beneficio pecuniario. Pues bien, todas estas corrientes doctrinarias parten del craso error, entre otros, de no asimilar el verdadero contenido de estos daños. Efectivamente, la objeción expuesta tendría cierto sentido si se identificase el daño moral con el pretium doloris, no hay que olvidar que este último consiste en el padecimiento o dolencia física y psíquica que causa en la víctima la lesión. Nosotros no compartimos esta definición porque típicos daños morales, como el atentado al honor, se indemnizan con indiferencia de la concomitancia o no de sufrimientos; además, no podemos soslayar que las personas privadas de conciencia perfectamente (como las que quedan en coma) tienen todo el derecho de percibir una indemnización, no siendo obstáculo para tal fin la imposibilidad de asumir cualquier sensación, pues lo que se indemniza es su dignidad de ser humano no el probable sentimiento padecido. Resulta evidente que la prueba de estos peculiares daños no se puede sujetar a los mismos parámetros objetivos utilizados en la demostración de daños patrimoniales; esta prueba tiene un importante contenido de subjetividad y su determinación se obtiene de la valoración de las condiciones y circunstancias que el buen sentido señala en cada caso concreto. En vastas ocasiones los perjuicios morales deben presumirse (incluso, no se olvide que en ciertas circunstancias hasta los mismos daños patrimoniales solo pueden presumirse como es el caso del lucro cesante o el daño emergente futuro). Pero ésta es presunción iuris tantum que, conforme a la vigente corriente de inversión de la carga de la prueba, corresponde al agente dañador desvirtuar el contenido de tal conjetura. Existe otra doctrina que rechaza la reparación del perjuicio moral basada en los peligros del arbitrio judicial; los partidarios de esta corriente de pensamiento sostiene que la obvia subjetividad del daño moral y la falta de susceptibilidad de equivalencia económica conducen a otro problema: el peligro del arbitrio judicial. En efecto, se dice que cualquier cantidad en metálico otorgada para reparar estos particulares perjuicios, tendría que ser inevitablemente arbitraria. también se afirma que la arbitrariedad de esta reparación consiste en que la víctima de un daño moral, que en principio no sufre ningún perjuicio de corte patrimonial, reciba una indemnización en metálico que incremente injustamente su patrimonio. Nosotros creemos que hablar de arbitrariedad en estos casos obedece a una ligereza en el uso del lenguaje. en verdad, se ha apreciado que a veces los propios daños patrimoniales no tienen una exacta traducibilidad monetaria y esto no es obstáculo para su reparación ni a nadie se le ocurre tildar al juez de arbitrario; como dice el jurista argentino PIZARRO (2000), "De lo expuesto surge que también en materia de daño patrimonial puede estar presente la discrecionalidad del juzgador para su determinación cuantitativa (discrecionalidad no es sinónimo de arbitrariedad" (p. 79). Efectivamente, ante unos daños eminentemente subjetivos, el juez debe valorar libre y prudencialmente las circunstancias particulares del caso concreto, en ello consiste su facultad discrecional; en cambio, una actitud arbitraria, denota un acto o proceder contrario a la justicia, la razón o las leyes, dictado sólo por la voluntad 
de forma indistinta el tema que ahora nos ocupa, como es la transmisión del derecho a la reparación del daño moral.

En nuestro ordenamiento jurídico, no tenemos mucha tradición sobre la reparación del daño moral o extrapatrimonial; nuestros tribunales no han sido prolíficos en jurisprudencia referida a este tema. Por ello, nos vemos compelidos a recurrir al Derecho comparado, especialmente el Derecho español, que tiene una extensa tradición jurídica referida a estos menoscabos.

Finalmente, no podemos obviar la transmisión del derecho a la reparación de estos daños no patrimoniales por actos entre vivos. Para analizar su viabilidad, es necesario determinar si con esta transmisión se satisface la función que desempeña la reparación del daño extrapatrimonial.

\section{Controversia en cuanto a la transmisión de la reparación de esta clase de menoscabos}

Esta temática, de evidentes tintes procesales, no pocas polémicas ha suscitado, sobre todo si se toma en cuenta su singular importancia práctica. No obstante, en la actualidad, la transmisibilidad del derecho a la reparación del daño moral escapa de cualquier controversia, cuando la víctima de esta categoría de menoscabo fallece después de interpuesta la acción, pues resulta claro que los herederos

o el capricho. Se opina que no hay nada más injusto, irracional y opuesto a los Principios Generales del Derecho que dejar sin indemnización a las víctimas de esta clase de perjuicios. Existe otra Teoría contraria a reparar el daño moral sustentada en la supuesta inmoralidad de compensar dolor con dinero. Según este criterio, resulta escandaloso compensar los bienes más excelsos del ser humano como el honor, los afectos más sagrados, los dolores más dignos de respeto, la integridad física, la salud etc., con dinero. Para defender esta postura se acude a drásticos razonamientos como preguntar ¿Cuánto cuesta la vida de una persona?. ¿Cuánto vale el honor de un ser humano? ¿Qué precio tiene el dolor de una mujer mancillada?. A priori, contestando estas preguntas, repugna a la idea de justicia tarifar pecuniariamente estos bienes. Sin embargo, el profesor italiano MINOZZI (1909) señala que este razonamiento parte del equívoco de confundir el concepto de la retribución de la cesión de un bien personal con el resarcimiento por daño a ese mismo bien. En el primer caso, constituye una inmoralidad el dinero que representa el precio de un bien invaluable e intransmisible. Pero en el segundo caso, el resarcimiento representa la cantidad adeudada por el daño ocasionado a aquel bien, siendo un resarcimiento honesto. No estamos hablando de una venta en la que se intercambien dinero y bienes morales. Quienes consideran inmoral la indemnización de esta categoría de daños, acuden al argumento de que la pretensión resarcitoria se apoya en una filosofía materialista de la vida. Para rebatir esta afirmación, no se debe dejar de citar las brillantes palabras con que el jurista argentino ORGAZ (1967) se refiere a este tema, "Resarcir los daños morales aunque sea de modo pecuniario -a falta de otro mejor-, no es materializar los intereses morales, sino, al contrario, espiritualizar el Derecho en cuanto éste no se limita a la protección de los bienes económicos y rodea también de seguridad a aquellos otros bienes no económicos, que son inseparables de la vida humana" (p. 186). 
podrán continuar con el juicio de acuerdo con las reglas generales de la sucesión procesal. Así, nos lo explica el jurista Álvarez Vigaray ( I 966):

Por lo que se refiere a la transmisibilidad a los herederos del derecho a la reparación del daño moral en general, no existe ningún obstáculo a que se efectúe la transmisión si el perjudicado por el daño había deducido ya en vida la acción para obtener la reparación, pues, en ese caso, sucederían en ella los herederos (p. 108)2.

\section{Igual solución se aplica en los casos de ejecución de sentencia, se habla de aque- llas situaciones en las cuales por medio de sentencia firme se había reconocido el derecho a la reparación del perjudicado antes de su deceso ${ }^{3}$.}

2 Este criterio está sustentado en Art. 1050 Pr que reza así: "Si antes de contestar la demanda muere la persona emplazada, se hará a sus representantes o herederos un nuevo emplazamiento.

Si ya contestada la demanda muriese el demandado, los trámites ulteriores se entenderán con sus herederos, o con el apoderado que lo representaba en el juicio y que no hubiesen removido dichos herederos.

Si los herederos no se personasen en el juicio, después de la muerte de su causante, la parte contraria podrá pedir al Juez que con ellos se entiendan los procedimientos, debiendo designar nominativamente quienes sean los herederos. Si éstos negasen la calidad de tales, se resolverá el artículo por los trámites de los incidentes Lo dicho en este artículo es aplicable también a los herederos del actor.

Si muriesen ambos litigantes, el juicio se seguirá entre unos y otros herederos.

Si los herederos estuviesen fuera del lugar del juicio, se procederá conforme Arto. 868.

Lo dispuesto en este artículo es sin perjuicio de las regla generales que los interesados quieran utilizar sobre declaración de herencia yacente.

Artos 60-78-869-1029 inc 2 Pr B.J 122-9633.

En España el Art. 16.1 LEC, que dice: "Cuando se transmita <<mortis causa >> lo que sea objeto del juicio, las personas que sucedan al causante podrán continuar ocupando en dicho juicio la misma posición que éste, a todos los efectos.

'Comunicada la defunción de cualquier litigante por quien deba sucederle, el tribunal suspenderá el proceso y, previo traslado a las demás partes, acreditados la defunción y el título sucesorio y cumplidos los trámites pertinentes, tendrá, en su caso, por personado al sucesor en nombre del litigante difunto, teniéndolo en cuenta en la sentencia que se dicte".

3 En virtud del silencio que guarda nuestra legislación al respecto recurrimos al Derecho comparado, concretamente al art. 540 LEC de España que establece:

"Ejecutante y ejecutado en los casos de sucesión.

'1. La ejecución podrá despacharse a favor de quien acredite ser sucesor del que figure como ejecutante en el título ejecutivo y frente al que se acredite que es el sucesor de quien en dicho título aparezca como ejecutado.

'2. Para acreditar la sucesión, a los efectos del apartado anterior, habrán de presentarse al tribunal los documentos fehacientes en que aquélla conste. Si el tribunal los considera suficientes a tales efectos, procederá, sin más trámites, a despachar la ejecución a favor o frente a quien resultare ser sucesor en razón de los documentos presentados.

'3. Si la sucesión no constare en documentos fehacientes o el tribunal no los considerare suficientes, de la petición que deduzca el ejecutante se dará traslado a quien conste como ejecutado en el título y a quien se pretenda que es su sucesor y, oídos todos ellos en comparecencia, el tribunal decidirá lo que proceda sobre la sucesión a los solos efectos del despacho de la ejecución”. 
El panorama cambia completamente cuando el lesionado por el daño moral fallece sin haber incoado la demanda de indemnización. Se ha dicho que en estas circunstancias la acción es intransmisible, porque de lo contrario existiría un enriquecimiento sin causa de parte del heredero o legatario (Planiol y G. Ripert, i 946, p. 846; Lambert-Faivre, i 99o, p. 174; Domínguez Hidalgo, 200ob, p. 735). En igual sentido, el civilista francés Demogue ( 1 924) arguye que "no cabe la transmisión porque una vez acaecida la muerte de la víctima, la reparación es inútil para la satisfacción de su interés" (p. 55). Otro argumento esgrimido para negar el derecho a la reparación de los herederos, consiste en que si el daño moral causa un detrimento en los sentimientos de afección o en los derechos de la personalidad, se deduce que la acción debe ser personalísima, como lo son tales derechos (Minozzi, 1909). Para la jurista española Gázquez Serrano (2000), el problema se agudiza cuando se constata que el ordenamiento jurídico "carece de una regla que establezca, y mucho menos regule el derecho a indemnización del daño por la muerte de una persona" (p. 27); empero, se puede tratar de sacar partido de este vacío legal y decir que no existe ninguna disposición jurídica que excluya la transmisión de la indemnización de los daños de la víctima inicial a sus herederos y, ubi lex no distinguit nec noc distinguire debemus. Como así lo afirma el profesor Álvarez Vigaray (i 966), “en los demás supuestos de daño moral, al no existir un precepto que prohíba la transmisión a los herederos del derecho a exigir la reparación, debe serle aplicado el principio general de transmisibilidad 'mortis causa' de los derechos de contenido patrimonial" (p. 109). Para otro jurista, las objeciones en contra de la transmisibilidad de la acción para obtener la reparación del daño moral no son convincentes en el plano jurídico, pero sí tienen cierto fundamento en el ámbito ético, porque se trata de que una persona pueda sacar beneficio del sufrimiento ajeno (Domínguez Hidalgo, 20oob, p. 731). En nuestra opinión, situándonos en terreno ético, el sentido común índica que repugna más a la ética que mientras quien lesiona a una persona se le obliga a indemnizar todo el daño, incluyendo el moral, por el contrario, quien priva de la vida del perjudicado, a pesar de la mayor gravedad del daño, no se le pueda constreñir a reparar el daño moral ocasionado al damnificado inmediato.

Debemos tener presente que una importante finalidad que se persigue al permitir la transmisibilidad de la acción de reparación del daño moral, consiste en impedir que este rubro de daños (causado a la víctima inicial) quede sin compensación, y nadie mejor que los herederos y/o perjudicados por el deceso de la víctima para certificar, como continuadores de su personalidad del causante, que esta reparación sea debidamente satisfecha. 
En virtud de estos señalamientos, paulatinamente ha surgido una opinión partidaria a admitir la transmisibilidad de la acción de reparación del daño moral padecido por el de cujus (Ravazzoni, ig62, p. 184; Scognamiglio, i957, pp. 321 y ss y 1962, pp. 74 y ss; DE CUPIS, I 975, pp. 667-669; García López, I 99o, p. 198); y para ello, no obsta que no haya sido introducida la demanda durante la vida del causante. Para sustentar esto, se ha cuestionado el "sacrosanto" carácter personalísimo de esta acción o, mejor dicho, se reconoce que la naturaleza del derecho violado tiene un carácter personalísimo, pero, el derecho al resarcimiento tiene por objeto una prestación pecuniaria que constituye un elemento integrante del patrimonio del lesionado $y$, como todo derecho patrimonial, se reviste de una factibilidad para ser transmitido a los herederos. De suerte que se distingue el daño, de contenido extrapatrimonial, y su reparación, "que es indudablemente de carácter patrimonial (Vicente Domingo, 1994, p. 236); en similar sentido, para el profesor Scognamiglio (i 957, p. 321 y 1962, p. 74):

Si bien la reparación se atribuye en virtud del dolor experimentado, ha de considerársele, conforme al argumento expuesto, como un derecho que se concreta en la pretensión de una prestación pecuniaria, y de este modo cae en el patrimonio del sujeto.

Conforme al jurista Madridejos Sarasola (i962), "Este derecho a la indemnización es un derecho patrimonial nuevo que, en general, puede considerarse transmisible como cualquier otro, sin que le sea aplicable la inseparabilidad peculiar de los derechos de la persona” (p. 175).

\section{Prohibición de la transmisión del derecho a la reparación del daño moral a los acreedores}

En nuestra opinión, en principio, la transmisibilidad de la acción de reparación del daño moral tiene un carácter restringido, que culmina en la persona de los herederos y/o perjudicados. Es decir, no se está hablando del típico daño material y de su reparación, ambos de contenido patrimonial y que por lo tanto no tienen ninguna limitación para ser transmitidos. En este caso, se hace referencia a bienes o derechos extrapatrimoniales lesionados, cuya reparación tiene un sustrato patrimonial. Como explica el catedrático Lacruz Berdejo (i 958), "Nos hallamos ante la transformación de una situación jurídica extrapatrimonial en un derecho patrimonial" (p. 206; consultar también a Díez-Picazo, I993, p. 744). Por esta razón, la acción de reparación no debe ser ejercitada por los acreedores del perjudicado directo, porque aquellos no han sufrido ningún malestar 
por el atentado y no pueden quejarse por un dolor moral padecido por otro ${ }^{4}$. Con respecto a los derechos extrapatrimoniales, dice el mismo autor antes citado, Lacruz Berdejo (I958),

No son ejercitables por los acreedores en virtud de una doble razón: su relación inmediata con la personalidad del titular, y su ineptitud para satisfacer la pretensión de los acreedores, cuyo crédito solo puede ser hecho efectivo con derechos de valor directamente pecuniario (p. 207).

En la misma línea doctrinal, expresa el jurista OrGAz (I 967), "se reconoce que la acción de reparación del agravio moral no puede ser cedida a terceros por el titular (art. 1445); ni puede ser ejercitada por los acreedores mediante la acción subrogatoria” (p. 218). En igual sentido se expresan los hermanos H. MAzEAUD, L. Mazeaud y J. Mazeaud ( 1978 , p. 679.) Además, los acreedores, a diferencia de los herederos, por ficción del ordenamiento jurídico, no son continuadores de la personalidad del causante.

\section{Legitimación iure proprio y/o iure hereditario}

Otra controversia, íntimamente vinculada con el presente tema, es aquella que trata de determinar si las personas que pueden reclamar la indemnización por las lesiones o muerte del perjudicado directo están legitimadas iure hereditario, es decir, por ser los herederos de la víctima, y/o iure proprio, o sea, por ser ellos los perjudicados directos por la muerte del interfecto.

En vista de la ausencia de un debate jurisprudencial y doctrinal en nuestro sistema jurídico que aborde esta materia, recurrimos al Derecho español; para comenzar, debemos destacar que en caso de muerte, más de alguna sentencia ha atribuido una partida indemnizatoria beneficiando de manera global a los herederos o familiares del extinto sin precisar qué cuantía le corresponde a cada uno ${ }^{5}$.

4 Art. 1870 C: "Los acreedores, después de haber perseguido los bienes de que esté en posesión el deudor, para realizar cuanto se les deba, pueden ejercitar todas las acciones y derechos de éste con el mismo fin, exceptuando los que sean inherentes a su persona: pueden también impugnar los actos que el deudor haya realizado en fraude de sus derechos". Este precepto es tomado del art. 1111 del Código civil español CC. Esta norma a su vez se inspira en el art. 1166 del Código francés que dice: "Sin embargo los acreedores pueden ejercitar todos los derechos y acciones de su deudor, a excepción de los que están exclusivamente unidos a su persona”. Por su parte, estos artículos se sustentan en el aforismo latino actio personalis moritur cum persona.

5 Por ejemplo la STS, 2a de 24-02-1968 (Ponente: Francisco Pera Verdaguer, RAJ 1968/1044) que dice, "La cuestión relativa a si, en cualquier caso, quien dolosa o culposamente causa la privación de la vida de una persona viene obligado a indemnizar, y sus aspectos previos referentes a si aquella 
Este fenómeno principalmente se manifestó en la Sala de lo Penal del Tribunal Supremo de ese país y está relacionado con la polémica de poder determinar si los familiares en caso de indemnización por causa de muerte instantánea de su pariente, reciben la reparación iure proprio o iure hereditatis; inclinarse por esta última postura, en opinión del jurista Pantaleón Prieto (i 989), muy probablemente obedezca a razones de facilidad para jueces y fiscales, pues de lo contrario, admitir la legitimación iure proprio significa tener que investigar individualizadamente "quiénes son y qué porcentaje de la reparación corresponde a cada uno de los afectados” (p. 617).

Las consecuencias de tal comportamiento son muy previsibles, la ciudadanía, incluyendo al profesional del Derecho, padece el flagelo de la incertidumbre de no saber, por una parte, el concepto detallado bajo el cual se le asigna la indemnización y, por otra, en caso de pluralidad de agraviados, se desconoce el importe que le corresponde a cada una de las personas sujetas a indemnización, esto último puede acarrear eventuales litigios por discrepancias en la forma de distribuir el monto indemnizatorio fijado de forma general. Además, existen también problemas prácticos que resultan de esta legitimación iure hereditatis, como por ejemplo, el absurdo, pero teóricamente viable caso en que el Estado pudiese reclamar la indemnización como último heredero ab-intestato, cuando el sujeto fallecido no ha dejado familiares o herederos sobrevivientes; o tener que compartir la herencia con un pariente muy lejano sin ningún tipo de vínculo afectivo; otra dificultad práctica que surge de repartir la indemnización entre los familiares según las cuotas hereditarias, consiste en que el cónyuge del extinto

privación supone un daño respecto de la misma persona, si el daño es evaluable y, finalmente si, de aceptarse las soluciones afirmativas, quién o quiénes tienen derecho al percibo de la indemnización, son temas tratados y resueltos por la doctrina en forma a veces discrepante, pero acerca de los cuales puede afirmarse que el criterio reiterado expuesto por esta Sala no es otro que el de responder con carácter de generalidad en sentido afirmativo las cuestiones enunciadas, y en cuanto a la última de ellas, concretamente en orden al sujeto preceptor de estas indemnizaciones, problema planteado en el segundo de los motivos del recurso, es doctrina constante que corresponde a los herederos de la víctima, a quienes se transmite la acción de acuerdo con lo previsto en el párrafo segundo del artículo 105 del Código Penal -sentencias de 30 de noviembre de 1930, 4 de marzo de 1944, 27 de noviembre de 1954 y 23 de junio de 1956- por su simple condición de tales sin necesidad de otra prueba alguna ...”. El procesado es acusado y condenado por delito de imprudencia temeraria por conducir con exceso de velocidad y arrollar a un peatón provocándole la muerte. Confrontar también la sentencia en, (1968) Jurisprudencia criminal, enero-febrero, pp. 756-759. Art. 105.2 del anterior Código Penal español Código Penal español, Decreto 3096/1973, de 14 de septiembre, Publicado en BOE de 12 de Diciembre de 1973), establece: "la acción para repetir la restitución, reparación e indemnización se transmite igualmente a los herederos del perjudicado". 
recibiese una reparación pecuniaria mucho menor que la de los hijos en común ya independizados (Pantaleón Prieto, 1989)6.

De suerte que, el mismo órgano superior judicial, consciente de esta situación ha abogado por desglosar de manera individual el importe de las reparaciones. En este aspecto resulta casi paradigmática la STS, 2a de 22 de octubre de 1975 que declara que "el Tribunal de instancia está obligado a efectuar una cuidadosa investigación de la situación real para fijar luego nominatum el orden de perjudicados y las cuotas de indemnización atribuibles a cada uno..." ; de forma análoga la STS, 2a , de 7 de octubre de 1985 establece que para la determinación exacta de los daños y perjuicios puede ser "práctica recomendable la de descomponer, la indemnización, en tantas partidas como sean los conceptos reparables o indemnizables, señalando una cantidad para cada uno de ellos, de tal modo que, solo sumándolas o adicionándolas se obtiene la suma total" ${ }^{\prime}$. La STS, 2a , de 15 de abril de 1988 expresa

... porque al fallecer una persona como consecuencia o resultado de un delito, surge la obligación de indemnizar, pero no por virtud del fenómeno sucesorio, puesto que el difunto nada llegó en vida a adquirir que, integrando su patrimonio, fuera luego objeto de transmisión mortis cau$s a$, sino sencillamente, porque, dándose los factores antes enumerados, en todo o en parte, en los próximos parientes, a ellos, como consecuencia del fallecimiento de la víctima de la infracción penal, corresponde ex novo y por derecho propio, y no por virtud de sucesión, el derecho de indemnización (...).

6 Art. 1008 C: "Si el difunto hubiere dejado hijos legítimos, la herencia se dividirá en cuatro partes: tres para los hijos legítimos y una para los hijos naturales o nietos naturales, sin perjuicio de la porción conyugal que corresponda al marido o mujer sobreviviente".

7 STS, 2a , de 22-10-1975 (Ponente: Fernando Díaz Paloz, RAJ 3970). En este caso se condenó al procesado como autor del delito de imprudencia temeraria con resultado de homicidio a la pena correspondiente junto con la obligación de indemnizar la cantidad de 500.000 pesetas a los herederos del interfecto con cargo al seguro obligatorio hasta el límite real. Contra este fallo se interpuso el recurso de casación alegando indebida aplicación del artículo 105, párrafo $2^{\circ} \mathrm{y}$ falta de aplicación del art. 104 [ambos del anterior $\mathrm{CP}$ ) en el sentido de que se manda a indemnizar a los herederos de la víctima de forma genérica sin ningún tipo de especificación tal como grado de parentesco y el perjuicio sufrido. ElTS acoge el recurso y ordena que en el trámite de ejecución de sentencia se determine el parentesco de los herederos y a la vista de su vinculación con el causante se atribuya con prioridad la indemnización decretada o, en su caso, la concurrencia de beneficiarios y cuotas respectivas de los mismos. Art. 104 del anterior Código Penal español, Decreto 3096/1973, de 14 de septiembre, Publicado en BOE de 12 de Diciembre de 1973), reza así: "La indemnización de perjuicios materiales y morales comprenderá no solo los que se hubieren causado al agraviado, sino también los que se hubieren irrogado, por razón del delito, a su familia o a un tercero".

8 STS, 2a , de 07-10-1985 (Ponente: Luis Vivas Marzal, RAJ 1985/4783). En esta causa penal se enjuicia y condena a los autores del delito de lesiones causadas en una riña tumultuaria. 
'...Por todo ello, los Tribunales de instancia, desechando toda inclinación a la comodidad, deben declarar en sus sentencias, nominatum y en cuanto sea posible, las personas a las que debe pagarse o satisfacerse la indemnización, así como la cuantía de la misma y la suma, cantidad o cuota que corresponde a cada uno de los beneficiarios" 9 .

\section{Esta tendencia de reafirmar la tesis que por causa de muerte solamente surgen pretensiones indemnizatorias iure proprio a favor de las personas perjudicadas por la muerte de la víctima, es decir, que descarta la expectativa resarcitoria iure hereditatis, es confirmada por numerosas sentencias ${ }^{10}$.}

$9 \quad$ STS, 1a, de 15-04-1988, (Ponente: Luis Vivas Marzal, RAJ 1988/2777). La sentencia de la Audiencia Provincial condenó al procesado Antonio G. M. como autor de un delito de imprudencia temeraria con resultado de muerte, a la pena de un año de prisión menor y privación del permiso de conducir durante tres años y a que abone a los herederos de la víctima la suma de 2.000 .000 de pesetas., las cuales serán satisfechas en primer lugar por la Compañía Minerva y hasta el límite del seguro obligatorio en lo que excedan con cargo al seguro voluntario y en su defecto por el procesado. Interpuesto el recurso de casación por el procesado y el responsable civil subsidiario Compañía Minerva, El TS declara no haber lugar al mismo.

10 Bajo esta orientación comulgan las resoluciones judiciales como la STS, 1a de 20-12-1930 (Ponente: Fulgencio de la Vega, RAJ 1930-1931/1365): "además que el derecho a la indemnización pretendida por los recurridos no provenía de su difunto padre, sino que les pertenecía por su carácter de mujer e hijos del atropellado, ya que éste, al fallecer instantáneamente [...] no llegó a poseer ni por un instante el derecho a ser indemnizado que se supone transmitió a sus descendientes, sino que con este acto nació para éstos la acción de indemnización, razón por la cual no tenía necesidad de justificar su carácter de herederos...”. En este proceso se contempló la petición de indemnización solicitada por la viuda y sus cuatro hijos por el atropello mortal que sufrió el progenitor y marido Consultar también este fallo de Jurisprudencia civil, no 197, noviembre-diciembre 1930, pp. 712-718. STS, 1a , de 25-02-1963 (Ponente: Tomás Ogayar y Ayllón): “... la indemnización de los daños morales y patrimoniales que con la muerte se causa a los más próximos parientes del difunto nace a favor de estos, cuando la muerte es instantánea, la acción directa de indemnización”. En este proceso se obtiene una indemnización de daños y perjuicios ocasionados a los perjudicados por el fallecimiento de un médico y de su hijo a consecuencia severas lesiones ocasionadas en una pelea. Cotejar sentencia en jurisprudencia civil, t. 116, febrero 1963, pp.600-612. El mismo lineamiento jurisprudencial se denota en la STS, $1^{\text {a }}$, de 0712-1968 (Ponente: Andrés Gallardo Ros, RAJ 1968/5835): “Que al establecer la resolución recurrida que los daños indemnizables han sido sufridos directamente por la actora quien accionó por su propio derecho y no como heredera de la víctima no ha aplicado los arts. 657,658 y $660 \mathrm{CC}$, ni tenía por qué hacerlo al faltar el supuesto contemplado en los mismos, ya que los daños morales y patrimoniales que con la muerte de una persona se causan, tienen como sujetos pasivos a los más próximos parientes del difunto y no forman parte del caudal hereditario de la víctima, no necesitan aquellos, por tanto, invocar su cualidad de herederos de la misma...”. En esta controversia se dilucida la reparación solicitada por la madre a causa de la muerte de su hija soltera que vivía con ella, víctima de un atropello provocado por un motociclista que invadió la acera. Ver también la STS, 1a , de 09-06-69 (Ponente: Emilio Aguado González, RAJ 1969/3353): "Que la indemnización por accidente que causa la muerte de una persona, no puede estimarse como derecho incorporado al patrimonio de la misma [...] de aquí que, la legitimación activa no implique la demostración de ser heredero del damnificado sino la del perjuicio directo sufrido por una persona distinta a causa del daño que genera la culpa extracontractual". Los daño y perjuicios fueron ocasionados por el hundimiento de un edificio destinado a sala de fiestas y restaurante propiedad del demandado, como consecuencia del percance resultaron varios muertos y lesionados. Igual postura se perciben en la STS, 1a, de 24-11-1970 (Ponente: Manuel Gon- 
A pesar de este saludable posicionamiento del Tribunal Supremo en pro de una detallada pormenorización del monto indemnizatorio, a veces, aún se presentan situaciones en que los fiscales y jueces de los tribunales de instancia continúan solicitando y concediendo indemnizaciones globales para los herederos en casos de muerte ${ }^{11}$. Ante este panorama, el Tribunal Superior ha tenido que afrontar el dilema de tener que elegir entre hacer caso omiso de esta ineficiencia de los funcionarios judiciales o, la no muy apropiada alternativa de admitir el recurso interpuesto por el agente dañador y absolverlo con la correspondiente eficacia de cosa juzgada en detrimento de los afectados, por defectos de falta datos y pruebas precisas sobre la determinación personalizada de los perjudicados y de la cuota particularizada del montante reparatorio. La respuesta ante esta disyun-

zález Alegre, RAJ 1970/4889) que se refiere a una reclamación de daños por la muerte en accidente de circulación del hermano de los demandantes en contra del conductor causante del accidente y su compañía aseguradora, la demanda fue estimada en primera instancia, pero la Audiencia desestimó la pretensión bajo el argumento que no se acreditó la condición de herederos de los demandantes, interpuesto el recurso de casación el TS casa la sentencia y declara que la indemnización por la muerte de una persona no puede considerarse como un derecho incorporado en el patrimonio de la víctima y por esta razón la legitimación activa no implica la demostración de ser heredero del damnificado, sino la de perjudicado por el daño sufrido por otra persona. Igual lineamiento se denota en la STS, 1a , de 04-05-1983 (Ponente: Jaime Santos Briz, RAJ 1983/2622). En este caso se ventila la reclamación por el fallecimiento de una persona en accidente de circulación, dos de los hijos del interfecto, a pesar de que se personaron en el proceso criminal, se abstuvieron del civil, la parte demandada, en el recuso de casación alegó la violación de la litis consorcio activo necesario, cuestión rechazada por el Alto Tribunal bajo el argumento de que los hijos del fallecido al no sentirse perjudicados no estaban obligados a comparecer en la acción civil, y esto demuestra que "... es el concepto de perjudicado, y no el de heredero del fallecido en accidente, lo decisivo para acordar la indemnización correspondiente y cualificar la oportuna legitimación activa”. Sin embargo, conviene destacar que esta Sala de lo Civil del Tribunal Supremo nunca ha rechazado demandas indemnizatoria en casos de muerte por el hecho de que la indemnización se solicitase en general para los herederos del fallecido, en vez de pedirlo individualmente para cada uno de los particulares afectados, ha considerado este "desliz" como un simple error formal intrascendente. F. PANTALEÓN PRIETO (1989, p. 640)

11 Ver STS, 2a ${ }^{a}$, de 12-05-1980 (Ponente: Mariano Gómez de Liaño y Cobaleda, RAJ 1980/1909), en esta causa criminal se condena al autor del delito de asesinato a una pena de veinte años y un día de reclusión y a indemnizar a los herederos con un cantidad global de un millón de pesetas sin desglosar las cuotas que corresponde a cada uno de los herederos. Otro ejemplo de esta postura se observa en la STS, 2a , 16-01-1975 (Ponente: José Hijas Palacios, RAJ 1975/129), en la cual se condena por imprudencia temeraria al causante de un accidente automovilístico por mala maniobra y con el resultado de cuatro personas fallecidas y siete heridas. En el fallo se condena al autor del delito a indemnizar por la muerte de una señora a su cónyuge y demás herederos. El procesado interpuso el recurso de casación por inaplicación del art. 104 del anterior Cp, por falta de precisión de los herederos, el TS desestima el recurso y dice, "En efecto la sentencia recurrida [...] establece, [...] una indemnización nominal a favor de su esposo y otra a favor de los restantes herederos de la misma, no en su calidad de herederos, sino de familia o perjudicados por dicha muerte, y aunque hubiera sido de desear que se concretara quiénes fueran, lo que no hizo la sentencia, sin embargo, se refiere a los demás familiares, perjudicados, que concurrieron con el marido a la herencia de la misma y observándose la edad de la fallecida -35 años y casada- es fácil que la intención del juzgador fuera hacerlo a favor de los padres de aquélla o demás hijos si los hubiere...”. Ver también la STS, 2a, 02-10-1975 (Ponente: Bernardo-Francisco Castro Pérez, RAJ 1975/3532). 
tiva, puede consistir en la decisión salomónica de acoger parcialmente el recurso y, sin privar a las víctimas de su resarcimiento, obligar en el proceso de ejecución de sentencia a suplir las indeterminaciones antes señaladas ${ }^{12}$.

Huelga decir que los órganos de justicia no "tropiezan" con estas vacilaciones de orden ético, cuando son los lesionados quienes interponen el recurso por considerar que la sentencia de la Audiencia Territorial les perjudica por otorgarles menos de lo solicitado (infra petitum) y por no desglosar las partidas indemnizatorias $^{13}$.

Estas "enmiendas" judiciales indican dos respuestas para un mismo problema, en el sentido de que si la sentencia es recurrida por el infractor, el recurso puede ser acogido parcialmente, en cambio, si la apelación es interpuesta por el sujeto pasivo de la acción dañosa, el recurso tiende a ser admitido en su plenitud. Si bien es cierto, esta solución se ajusta más a los parámetros de equidad, pero, en detrimento del Derecho, pues desde el punto de vista jurídico, no se puede dar soluciones diferentes para casos iguales. Es decir, por injusto que sea, en estricto Derecho se debería también amparar favorablemente el recurso introducido por el responsable. Sin embargo, lo inicuo de esta situación, en la cual la víctima quedaría sin la tutela de la justicia, demuestra la imperiosa necesidad de extirpar esta nociva costumbre de los tribunales de justicia españoles de conceder indemnizaciones en globo.

12 Precisamente esta es la solución adoptada por la referida sentencia de 22-10-1975, “... pues realmente la sentencia de instancia debió discriminar si el interesado interfecto dejó o no parientes, grado de dicho parentesco y, por ende, el perjuicio de todo orden sufrido por ellos, sin que, no obstante, deba acogerse totalmente el recurso y denegar la indemnización decretada por el Tribunal a quo, con el riesgo evidente de dejar en desamparo a las víctimas del delito en cuyo nombre ejerció el Ministerio Fiscal la acción reparatoria; tanto más que el vacío fáctico de la sentencia -que pudo y debió ser colmado por el recurrente utilizando otra vía casacional- puede ser suplido en trámite de ejecución de sentencia, una vez que se acoge el recurso de casación en el limitado sentido expuesto, de que los "herederos" del extinto deben acreditar en dicho trámite su relación parental con aquél y a la vista de su respectiva vinculación se determine la cuota de indemnización atribuible a cada uno".

13 Este es el caso de la STC, 2a , de 13-06-1986 (Ponente: Jesús Leguina Villa, RATC 78/1986) que acogió favorablemente el recurso de amparo interpuesto por el perjudicado porque consideraba que el fallo en mención socavaba la tutela judicial efectiva consagrada en el artículo 24.1 de la Constitución Española). El demandante solicitó una indemnización general de 6.391 .818 pesetas en concepto de lesiones, 48.556 .154 por secuelas, 343.976 por gastos de curación y 30.000 por daños materiales. De toda esta cantidad el Juzgado de instancia solo le concedió una indemnización global de 1.130.000 pesetas, razón suficiente para que el lesionado alegara que el Juzgado de instrucción no fijó de manera detallada los daños causados, ni expuso los conceptos determinantes de la reparación ni los fundamentos legales. El Tribunal casó la sentencia y declaró que los jueces deben hacer "una estimación razonada de la cuantía alcanzada" por los distintos daños producidos, sin que sea suficiente la formularia y cómoda afirmación, típica de la jurisdicción criminal, que todo responsable de un delito también lo es civilmente, con mera invocación del artículo 19 del antiguo Código Penal, fijando después, de forma abstraída y sin más las indemnizaciones reputadas pertinentes”. 
En esta investigación se comparte la opinión de que un familiar cercano a la víctima mortal, unido a este último por sólidos vínculos afectivos, puede perfectamente estar legitimado para reclamar una indemnización tanto por derecho propio como en su cualidad de heredero; es decir, ambas posturas doctrinales necesariamente no tienen que excluirse entre $\mathbf{s}^{14}$; además, no creemos que admitir la legitimación iure hereditatis de los parientes del interfecto sea la causa de la falta de precisión de las cuantías indemnizatorias, una cosa no implica necesariamente la otra. De manera que aunque no necesariamente coinciden ambas situaciones de estar legitimados para reclamar la indemnización iure hereditario y iure proprio, la mayoría de veces se armonizan tales circunstancias, así los parientes del causante podrán ejercitar su acción tanto por ser sucesores del mismo, como por sufrir personalmente las consecuencias del evento dañoso.

\section{Consecuencias prácticas}

De acuerdo con los estudiosos del Derecho, la escogencia de cualquiera de estas dos líneas doctrinales tiene importantes y diversos efectos prácticos. Así, se ha dicho que si la indemnización se fundamenta en la acción iure sucessionis, los herederos deben de antemano acreditar su condición de tales mediante el testamento o a través de la correspondiente declaración ab-intestato con los respectivos gastos y molestias (Rajoy Sobredo, 1973, p. 58).

Además, se afirma que el caudal hereditario quedaría sujeto al abono de impuestos con los que se pagan las transmisiones sucesorias ${ }^{15}$, así como también que

14 En este sentido, ver la STS 01-07-1981 (Ponente: Jaime Santos Briz, RAJ 1981/3037) que permite la coexistencia de ambas pretensiones resarcitorias: “... o en todo caso se impone en estos supuestos considerar en los reclamantes una doble cualidad; como perjudicados <<iure proprio >> y como herederos de la víctima”. En esta litis se condena a los responsables y a sus compañías aseguradoras a indemnizar a los herederos y perjudicados por el fallecimiento de una señora en accidente de tránsito (en este fallo se cita la sentencia de 19-11-1966/5880). De igual manera la STS, $1^{\text {a }}$, de 04-05-1983/2622, que se acaba de citar dice: “... aunque es frecuente que ambas cualidades concurran en las mismas personas...”.

15 La Ley $\mathrm{N}^{\circ}$ 453, Ley de equidad fiscal, publicada en La Gaceta, Diario Oficial $\mathrm{N}^{\circ}$ 82, del 6 de mayo de 2003, en lo sucesivo Ley 453/2003, en su Artículo 6 establece: "Renta ocasional. Será considerada como aumento de renta, la renta ocasional obtenida por la enajenación, permuta, remate, dación o adjudicación en pago, fideicomiso o cualquier otra forma legal de que se disponga de bienes muebles o inmuebles, acciones o participaciones de sociedades y derechos intangibles.

'También se considerarán como aumentos de renta, los beneficios provenientes de las herencias, los legados y las donaciones, así como de las loterías, los premios, las rifas y similares.

La renta ocasional y beneficios descritos en los párrafos anteriores están sujetos a retenciones en la fuente o a pagos a cuenta del IR anual, en la oportunidad, forma y monto que determine el Poder Ejecutivo en el ramo de hacienda".

Por su parte, la Ley 822, Ley de concertación tributaria, publicada en La Gaceta, Diario Oficial No 241, del 17 de diciembre de 2012, en lo sucesivo Ley 822/2012 indica en la parte in fine del art. 15, 
dicho montante sucesorio estaría propenso a cubrir las deudas del causante con lo que se desnaturalizaría la indemnización y la finalidad reparatoria; así, para el maestro De Castro y Bravo (1956) "la indemnización solicitada por los derechohabientes, al entrar en el acervo hereditario, responde a los acreedores del causante” (p. 479). Sobre este tema dice el catedrático López JAcoiste (I 993), "La diferencia entre los dos planteamientos se hace tangible en el orden práctico. Pues todo lo que se agregue al relictum vendrá sujeto a las posibles reclamaciones por parte de los acreedores de la herencia y al correspondiente impuesto sucesorio...” (p. 1562). Tal efecto no se produciría si los interesados interponen su acción iure proprio.

Por otra parte, la sucesión intestada puede originar situaciones extremo injustas al otorgar similares indemnizaciones a parientes que, por sus circunstancias de vínculos afectivos o dependencias económicas, merezcan un tratamiento diferenciado (RAjoy SobRedo, 1973, p. 58); escenario que no ocurriría, si el perjudicado interpone su acción por derecho propio; pues, en esta situación, cada uno de los afectados debe probar la magnitud de su menoscabo. Con esto se alude a otro importante efecto práctico concerniente al aspecto probatorio. De verdad, se dice que si se solicita la indemnización iure sucessionis, solo se tiene que probar la condición de heredero; así afirma el maestro De Castro y Bravo (I956),

En caso del homicidio se dan algunas particularidades, que bastará ahora- señalar. Ante todo, el perjuicio sufrido por la víctima no necesita ser probado, pues consiste en la pérdida de su vida, y este hecho es el que tipifica el delito (p. 476).

Más adelante, el mismo autor recalca esta idea al decir que "La prueba [del daño en caso de muerte] resulta superflua, porque está comprendida en el homicidio, hecho-causa del derecho" (p. 492) ${ }^{16}$; pero ha de pedirse una sola indemnización para todos ellos que entrará en el caudal hereditario, en cambio, si se demanda

inciso II: "Son ganancias y pérdidas de capital, las variaciones en el valor de los elementos patrimoniales del contribuyente, como consecuencia de la enajenación de bienes, o cesión o traspaso de derechos. Asimismo, constituyen ganancias de capital las provenientes de juegos, apuestas, donaciones, herencias y legados, y cualquier otra renta similar.

16 Sobre este punto la STS, 2a , de 23-01-1948 (Ponente: José María Castelló y Madrid, RAJ 1948/194) dice, "Que en los casos de homicidio por imprudencia, a los efectos de la responsabilidad civil, no es necesario que se demuestre la existencia de perjuicios, pues la realidad de los mismos surge de modo indudable por la muerte de la víctima del accidente, que es el efecto más grave e irreparable, transmitiéndose la correspondiente acción a los herederos...”. Este fallo versa sobre un delito de imprudencia temeraria causada por el chofer de un autobús que dando marcha atrás atropello a una anciana causándole inmediatamente la muerte. Confrontar sentencia también en Jurisprudencia criminal, enero-abril 1948, pp. 63-68. 
la reparación iure proprio se debe demostrar la entidad del daño, significa esto que recae sobre el actor el peso de la carga de la prueba de forma individual, por esto habrá tantas acciones como perjudicados sin limitación de cantidad de agraviados ni de cuantía.

Desde otro punto de vista, y no por obvio se debe dejar de mencionar, cuando la legitimación se fundamenta en el derecho sucesorio, el heredero actúa en nombre del de cujus, en cambio, actuando por derecho propio, como su nombre lo indica, invoca el perjuicio por él mismo padecido, como consecuencia del deceso de la víctima (SÁnchez VázQuez, I973, p. 2.). Por este motivo, se dice que en caso de culpa de la víctima mortal, si la acción se interpone por derecho propio, la culpa de ella no puede ser alegada en contra de las víctimas por repercusión para reducir la partida indemnizatoria, debido a que el perjuicio padecido iure proprio nada tiene que ver con la eventual culpabilidad del finado; En cambio, si se interactúa vía iure hereditatis, al actuar los descendientes en nombre del de cujus, están sujetos a las obligaciones de éste, entre las cuales está la de soportar la reducción de la indemnización en estos casos (Domínguez Hidalgo, 200ob, p. 745$)^{17}$.

También se puede decir que ambas titulaciones, por ser diferentes, no se interponen simultáneamente. La acción vía iure hereditario data de la fecha del accidente, porque a partir de ese momento surgen todos los daños morales y materiales, pero, si el perjudicado actúa ex iure proprio, el daño data desde el fallecimiento de la víctima directa (SÁnchez VÁzQuez, ı973, p. 2).

Por otra parte, la resolución judicial sobre una de estas dos acciones no produce el efecto de cosa juzgada sobre la otra, porque se trata de distintas acciones basadas en diferentes derechos, una es a título de sucesor y la otra es en virtud del menoscabo personalmente padecido (SÁnchez VázQuez, I 973, p. 2).

Por último, se advierte que la adopción de la vía sucesoria proporciona mayor seguridad y certeza, pues los herederos son previamente reconocibles, en cambio, el concepto de perjudicado es más complejo de determinar; debido a estas razones, el magistrado Alonso Prieto (I972) señala que "En síntesis cabe

17 Aunque esta jurista, con acierto, se decanta por la tesis de la oponibilidad de la reducción del monto indemnizatorio por culpa de la víctima directa porque de lo contrario sería absurdo que la víctima indirecta en determinados aspectos se base en las relaciones que la unían con el perjudicado directo, pero en otros pretenda desconocerlas en lo que le desfavorecen. Además, no se comprende una solución en la que la víctima por repercusión obtenga más provecho que la propia víctima directa (DOMÍNGUEZ HIDALGO, p. 746.) 
afirmar que el cambio de sistema, del iure hereditario al iure propio se traduce en que todo lo que se ha ganado en el terreno de la equidad, se ha perdido en el de la certidumbre y seguridad" (p. 429).

Los detractores de la legitimación iure hereditario parten de la concepción de que la muerte padecida por la víctima del evento dañoso no da lugar al nacimiento de ningún derecho que ingrese en su patrimonio y que, por consiguiente, pueda ser transmitido a sus herederos. Estos últimos solo pueden optar a sus pretensiones indemnizatorias iure proprio ${ }^{18}$.

También arguyen que "el derecho que pudiera asistir al difunto por privársele de la vida, es un derecho tan íntimo y personalísimo que difícilmente puede pensarse que sea susceptible de transmisión” (Soto NiEto, i 970, p. 86) ${ }^{19}$.

De igual manera, se aduce que solamente la víctima puede determinar si el daño padecido tiene la entidad suficiente para que sea oportuna la reparación, además, que, al soportar ella el menoscabo moral, puede precisar con mayor acierto la verdadera magnitud y extensión del agravio, por el contrario, la valoración realizada por los herederos será completamente arbitraria (Álvarez Vigaray, 1966, p. 108) $)^{20}$.

Por otra parte, ya hemos mencionado que la legitimación iure hereditario puede conducir al absurdo, pero teóricamente probable caso de que, en ausencia de otros herederos, el Estado pueda ser considerado como beneficiario de la indemnización por daño extrapatrimonial causado por el óbito de la víctima ${ }^{21}$. Sobre

18 Si como se verá con posterioridad, por una parte, lo que origina la responsabilidad no es la muerte en sí misma considerada, sino el hecho que la causa, y por otra, si la invención de la muerte inmediata es una creación más artificiosa que científica, no se concibe por qué la obligación de reparar el daño causado no puede formar parte del patrimonio de la víctima directa y luego engrosar su caudal hereditario.

19 Se refuta esta aseveración cuando se considera que aun cuando el daño concerniente en la privación de la vida, como cualquier daño moral, es de una naturaleza íntima y personal, su reparación por lo general se concreta en una suma de dinero de evidente contenido patrimonial y por ende susceptible de ser transmitida.

20 La consistencia de esta afirmación se derrumba desde el momento en que se considera que el problema de la arbitrariedad (entendida en el sentido de que depende del arbitrio) en la valoración del daño extrapatrimonial es connatural al mismo y aun en caso de que sobreviva la víctima, la determinación del quantum indemnizatorio no puede dejar de estar sujeta o a la discrecionalidad del juzgador o la arbitrariedad de un baremo.

21 Esta observación es formulada por la STS, 2a , de 01-02-1974 (Ponente: Luis Vivas Marzal, RAJ 1974/365) la cual establece que para transmitir la acción de restitución, reparación o indemnización a los herederos, según el art. 105, párrafo segundo[del anterior Código Penal], sería indispensable que el causante hubiera previamente adquirido la titularidad de dicha acción, lo que resulta absolutamente imposible porque la misma ha nacido precisamente en virtud de su muerte. Se agrega que 
este aspecto el jurista Gómez Orbaneja (i 949) cita el ejemplo de un inválido o un vagabundo que fallece por la imprudencia de un practicante en un hospital o por un accidente automovilístico o ferroviario y que no deje testamento ni parientes dentro del cuarto grado, pues en este caso considera "absurdo que se indemnice al Estado “¡como sucesor legítimo del muerto!” (p. 197). El mismo señalamiento es efectuado por el maestro Pantaleón Prieto (i 989, 617) 22.

\section{Se afirma, siempre dentro de esta controversia, que no se puede indemnizar el daño moral en los casos de muerte inmediata, porque el difunto no tuvo tiempo}

"esta doctrina es, además, la más práctica y la que no conduce a soluciones absurdas tales como la de que, con el juego de la sucesión testamentaria, pueda ser beneficiario, como heredero, un pariente muy lejano o un extraño, o, con el de la sucesión 'ab intestato', sea el Estado el agraciado”. En este proceso se juzgó al autor de un delito de imprudencia temeraria, la sentencia del tribunal de instancia le condenó a la pena correspondiente y al pago de una indemnización de 500.000 ptas., para los herederos del interfecto. Contra este fallo la parte acusadora recurrió en casación alegando infracción de art. $104 \mathrm{CP}$, por inaplicación, y del 105 del mismo cuerpo legal, por aplicación indebida. El TS estimó favorablemente el recurso y mediante una nueva resolución judicial condena al procesado a las mismas penas de la sentencia de instancia y al abono de 500.000 ptas., a la viuda del fallecido y, en caso de que hubiere dejado padres, se le sanciona con el pago de 400.000 pesetas para ella y 100.000 pesetas a repartir por parte igual entre los progenitores. De forma igual se pronuncia la STS, 2a ${ }^{\text {a }}$ 15-04-1988 (RAJ 1988/2777) antes citada. La probabilidad de que el Estado sea declarado heredero de la víctima es contemplada por el Art. 1001 C: Son llamados a la sucesión intestada: .... 8o Los municipios. El orden de sucesión es el que se indica en el Título subsiguiente. Art. 1019 C: "a falta de todos los herederos ab intestato, designados en los artículos precedentes, sucederán los municipios, según las reglas siguiente". Art. 1020 C: "El municipio llamado a la sucesión es el correspondiente al lugar del domicilio del causante. Si éste nunca hubiere tenido su domicilio en la República, corresponden los bienes a los municipios donde se encontraren a la muerte de aquel, declarándose heredero al Municipio donde hubiere más bienes y considerándose a los otros municipios como legatarios. Si los bienes no están situados en la República, pertenecen al Municipio del lugar del nacimiento; y si éste no ocurrió en ella, el Presidente de la República determinará el Municipio a que correspondan. Los Municipios no tomarán posesión de la herencia sin que preceda sentencia que los declare herederos, en los términos que ordena el Código de Procedimiento". Cabe destacar que El caudal relicto heredado por el Estado se destinará a obras de beneficencia o instrucción pública (art. 1021 C). En el Ordenamiento jurídico español el art. $956 \mathrm{CC}$ contempla esta situación en los siguientes términos: "A falta de personas que tengan derecho a heredar conforme a lo dispuesto en las precedentes Secciones, heredará el Estado, quien asignará una tercera parte de la herencia a Instituciones municipales del domicilio del difunto, de Beneficencia, Instrucción, Acción social o profesionales, sean de carácter público o privado, y otra tercera parte, a Instituciones provinciales de los mismos caracteres, de la provincia del finado, prefiriendo, tanto entre unas como entre otras, aquéllas a las que el causante haya pertenecido por su profesión y haya consagrado su máxima actividad, aunque sean de carácter general. La otra tercera parte se destinará a la Caja de Amortización de la Deuda pública, salvo que, por la naturaleza de los bienes heredados, el Consejo de Ministros acuerde darle, total o parcialmente, otra aplicación”. Pese a estos señalamientos jurisprudenciales y legislativos, la inviabilidad de considerar al Estado como heredero de los perjuicios extrapatrimoniales experimentados por la víctima mortal del acaecimiento dañoso, radica en el carácter restringido que se propone para la transmisión por causa de muerte del derecho a la reparación del daño moral.

22 En Nicaragua se reconoce el Derecho a la sucesión intestada hasta el sexto grado según el art. XVIII del Título preliminar del C y art. 1016.2 C. 
de padecer ningún sufrimiento, o estuvo inconsciente, y por lo tanto no hay nada que reparar ${ }^{23}$.

Finalmente, arguyen como razón definitiva y radical que la vida y el morir no son resarcibles J. J. López JAcoiste (I 993 p. 1568$)^{24}$, por lo tanto el acontecimiento de la muerte no da lugar al nacimiento de ningún derecho que ingrese en el patrimonio de la víctima y por lo tanto no es posible su transmisión a los herederos.

\section{Evolución jurisprudencial adoptada por cada una de las Salas civiles y penales del Tribunal Supremo español}

Además de las sentencias ya citadas, merece la pena bosquejar el recorrido que han efectuado tanto los tribunales civiles como penales con respecto a este tópico. En un principio, se percibía una divergencia de criterios de parte de los magistrados en ambas sedes de la responsabilidad. Así, mientras en ámbito civil persistía una posición propensa a admitir la legitimación iure proprio de los perjudicados, en la esfera penal los jueces consideraban que el derecho a la indemnización forma parte del acervo hereditario del interfecto que se transmitía a sus sucesores.

Buena prueba de estas tendencias se desprenden de las sentencias de los tribunales civiles como la de 20 de diciembre de 1930 (Ponente: Fulgencio de la Vega, RAJ 1930-1931/1365, Resolución antes citada) referente a la petición de indemnización solicitada por la viuda y sus cuatro hijos por el atropello mortal

23 No se comparte esta opinión porque aun en caso de muerte inmediata se deben indemnizar los daños morales aunque la víctima mortal no haya experimentado ningún dolor porque lo que se indemniza no es necesariamente ese dolor, sino que se compensa su dignidad de ser humano que se ve vulnerada en su máxima expresión, con la privación de la vida. Negar la indemnización del daño extrapatrimonial en estos casos, argumentado esa incapacidad de sentir, es tan injusta como descartar la reparación del daño no patrimonial ocasionado a personas que, como producto del percance, se ven privadas de su conciencia y por lo tanto no pueden sentir o padecer ningún sufrimiento.

24 Según BERCOVITZ Y RODRÍGUEZ-CANO (1976), "Parece evidente que la muerte no se puede indemnizar, y no por perjuicios doctrinales, sino todo lo contrario. De ahí que resulte incorrecto entender que la muerte da lugar a una indemnización que corresponde al patrimonio del fallecido y, a través de él, pasa a sus herederos" (p. 203). En armonía con este planteamiento la STS, 2a de 2110-1981 (Ponente: Manuel García Miguel, RAJ 1981/3862) afirma que los titulares del derecho a la indemnización "no son los herederos, sino los perjudicados que resulten tales por haber sufrido un daño material o moral como consecuencia de la muerte de la persona de que se trate, pues como es notorio que, según nuestro ordenamiento civil, tan solo las personas pueden ser objeto de derechos y la personalidad se extingue por la muerte (art. $32 \mathrm{CC}$ ), es evidente que de lo que se privó al muerto -la vida- no es susceptible de restitución, ni tampoco de reparación...”. Este argumento se desvanece pues, como se ha dicho y se recalcará más adelante, lo que origina el deber de reparar el daño es el acto que produce el deceso y no la muerte en sí misma considerada. 
que sufrió el progenitor y marido. Los demandados interpusieron el recurso de casación alegando que la parte actora debía acreditar su condición de herederos. El recurso no prosperó y la Sala, una vez acreditada el vínculo de parentesco entre los reclamantes y la víctima, acordó que el derecho a la indemnización no provenía de su difunto padre y esposo, sino que les pertenecía por su condición de mujer e hijos del accidentado, ya que con la muerte instantánea de éste último, no llegó a poseer ni por un instante el derecho a ser indemnizado que se supone transmitió a sus herederos, sino que por ese acto nació para éstos la acción de indemnización, razón por la cual no tenía necesidad de justificar su carácter de herederos ${ }^{25}$.

Igual lineamiento se desprende de la STS de 8 de enero de 1946 a través de la cual se concedió una indemnización a la viuda y madre de un carretero fallecido al ser arrollado por un tren. El Tribunal estimó que la obligación de indemnizar y el correlativo derecho de las demandantes nacieron a su favor por la omisión culposa productora del daño y por aplicación al caso de los preceptos contenidos en los artículos 1.089, 1.093 y $1.902 \mathrm{CC}$, sin que el título de ese derecho sea la sucesión del interfecto, sino la propia ley, por lo que, para hacer efectiva la obligación correspondiente, no precisaban acreditar el carácter de herederas de aquel, ni presentar documento alguno con la demanda ${ }^{26}$.

En la STS, 1ª, de 17 de febrero de 1956 (RAJ 1956/1103), esta Sala mantiene su criterio al otorgar una reparación a los padres de una chica de 15 años que falleció ahogada al caer a la mar empujada por el desprendimiento de mercancías de un barco que atracaba en el puerto de Vigo. La indemnización se les concedió a los demandantes no en concepto de herederos de la interfecta, sino como directamente perjudicados.

En la resolución judicial de 07 de diciembre de 1968 (RAJ 1968/5835), esta misma Sala resolvió el proceso en el que una madre reclamaba una indemnización por el atropellamiento de su hija soltera con la que vivía. La parte demandada, entre varias excepciones, opuso la de falta legitimación activa, por actuar la demandante en nombre propio y no como heredera. El tribunal rechazó la excepción y declaró que los daños morales y patrimoniales que con la muerte de una persona se causan, tienen como sujeto pasivo a los más próximos parientes

25 Ver sentencia en p. 9 del presente trabajo.

26 STS, 1ª , 08-01-1946 (Ponente: Manuel Ruiz Gómez). Ver sentencia en Jurisprudencia civil (1946), nueva serie t. XIII, enero-febrero, pp. 42-56. 
del difunto y no forman parte del caudal hereditario de la víctima, no necesitando aquellos, por tanto, invocar su cualidad de herederos de ésta ${ }^{27}$.

La misma doctrina se evidencia en el fallo ya citado de 09 de junio de 1969 (RAJ 1969/3353) en el que se adujo que la indemnización por accidente que causa la muerte de una persona no puede considerarse como incorporada al patrimonio de la misma, por la simultaneidad del nacimiento de tal derecho y el óbito de quien ya no puede ostentar personalidad jurídica para asumirlo, y de aquí que la legitimación activa no implique la demostración de ser heredero del damnificado, sino la del perjuicio directo sufrido por una persona distinta a causa del daño que genera la culpa extracontractual.

Reitera esta doctrina la sentencia de TS de la Sala 1a núm. 1055/1996 de 14 de diciembre RJ 1996/8970 que establece:

... pero puede afirmarse, en términos generales, que la legitimación para reclamar resarcimiento en caso de muerte corresponde, de ordinario, a los más próximos parientes de la víctima, si bien «iure propio» y no por sucesión hereditaria, prescindiendo de la distinción entre muerte instantánea y muerte ocurrida con posterioridad al accidente, pero debida a éste, para determinar si la indemnización por causa de muerte entra en el patrimonio del difunto y por ello transita a sus herederos o no... ${ }^{28}$.

En la STS de 24 de noviembre de 1998, se declara que "es reiterada y constante la doctrina jurisprudencial, según la cual la condición de perjudicado, bien sea por hechos delictivos como cuasidelictivos, no necesariamente coincide con la de heredero, sobre todo la muerte de un ser querido no incorpora a su as hereditario ningún derecho de contenido patrimonial nacido de su propia muerte..."29.

Más reciente la STS 1021/2008 de 3 de noviembre de 2008 de la Sala Primera de lo civil expresa

Estos perjudicados tienen un derecho al resarcimiento como derecho propio, no adquirido por sucesión hereditaria, según la jurisprudencia

27 Sentencia ya citada en la página 9 de este artículo.

28 STS, 1ª de 14-12-1996 (Ponente: Eduardo Fernández-Cid de Temes, RJ 1996/8970). Recuperado el 7 de noviembre de 2013, en http://aranzadi.aranzadidigital.es/maf/app/search/run/multi\#

29 STS, 1a, de 24-11-1998 (Ponente: Jesús Marina Martínez-Pardo, RAJ 1998/9694). La demanda fue introducido por los progenitores del fallecido quien perdió la vida electrocutado por falta de medidas de seguridad por parte de la empresa subcontratista y la empresa comitente. 
invocada por la parte recurrente, a tenor de la cual este derecho surge iure proprio [por derecho propio] y no iure hereditatis [por derecho de herencia]. Este rasgo característico del derecho de los perjudicados no altera el hecho de que los daños y perjuicios causados por una muerte a los allegados del fallecido son daños o perjuicios indirectos o reflejos, derivados del fallecimiento, por cuanto solo pueden dar lugar al nacimiento de una obligación de resarcimiento cuando el fallecimiento tiene su causa en un hecho imputable al agente causante del daño ${ }^{30}$.

En un sentido manifiestamente contrario se expresó la Sala Segunda del Tribunal Supremo, bajo una tendencia proclive a titulación iure hereditario de los sucesores del de cuius, para reclamar el derecho a la reparación. Conforme a este lineamiento, se muestran decisiones judiciales como la del 30 de noviembre de 1932, en la que el Tribunal sienta la doctrina de que es indudable que el interfecto, al perder la vida, sufrió un perjuicio irreparable, que, en lo posible, debe ser objeto de estimación económica y de indemnización a favor de sus herederos, que la ley o la voluntad del interfecto designen como tales según expresamente previene el art. 125 [del Código Penal español de $1870 \mathrm{Cp}]^{31}$.

Esta tendencia se reitera en la resolución judicial de 4 de marzo de 1944 (RAJ 1944/355) en la que se establece indemnizar a los desconocidos herederos de una persona muerta por un accidente ferroviario, cabe mencionar que la víctima mortal ni siquiera pudo ser identificada, a pesar de ello, se declara,

...que al ser la muerte un perjuicio de indiscutible estimación por sus efectos directos, totales e irreparables para la víctima, es obvio que el derecho a percibir el importe de esa valoración que dicha víctima no pudo hacer efectivo por sí misma a causa de su propia muerte, ipso facto y al amparo de lo que establece el párrafo segundo del art. 105 del mencionado Código se transfiere a favor de aquellas personas a las cuales la voluntad del interfecto o en su defecto la ley, hubiese en su caso, designado como herederos, toda vez que el hecho de la muerte por sí solo es el que originó y da nacimiento al ejercicio del derecho sucesorio.... ${ }^{32}$.

30 STS, 1a 03-11-2008 (Ponente: Juan Antonio Xiol Ríos). Recuperado el 7 de noviembre de 2013, de http://app.vlex.com/\#search/content_type:2/da\%C3\%B1o+moral+transmisi\%C3\%B3n+iure+proprio+iure+hereditario/vid/50694490

31 STS, 2a , de 30-11-1932 (Ponente: Eduardo Iglesias Portal, RAJ 1932/2178). Este caso versa sobre el atropello mortal que sufrió la víctima en un accidente de tránsito. Ver sentencia también en Jurisprudencia criminal (1932), no 127, julio-diciembre pp. 237-239.

32 En este litigio se procesa al autor del delito de imprudencia temeraria, quien trabajaba para una compañía de ferrocarriles y de forma imprudente permitió la entrada por una vía muerta de una máquina que provocó un accidente del que resultó muerto un individuo desconocido y lesionado otros dos más. 
Cabe destacar que mediante este procedimiento se otorga una indemnización en globo sin precisar, ya no el monto que corresponde a cada heredero, sino que ni siquiera se individualiza a cada uno de los sucesores del interfecto; esta es la interpretación que se desprende de la sentencia de 27 de noviembre de 1954 en los siguientes términos:

... el segundo de los motivos del recurso quiere presentar como infringido el artículo 104 del Código Penal tan solo porque la indemnización a que se condena al responsable subsidiario es a favor de los herederos del perjudicado, y no al de unos familiares o de personas determinadas y ciertas, alegación que ha de ser rechazada en absoluto, pues dicho pronunciamiento no resulta opuesto al espíritu y la letra del mencionado artículo, sino en un todo acorde con el uno y con la otra, ya que habiendo resultado muerta la víctima por razón del hecho de autos, es a sus herederos a quienes se transmite la acción para repetir por razón del mismo, según declara expresamente el párrafo segundo del artículo 105 del propio Cuerpo legal, y quienes por el solo hecho del fallecimiento del difunto suceden a éste en todos sus derechos y obligaciones, a tenor del artículo 661 del Código Civil ${ }^{33}$; asumiendo, por tanto, la personalidad del agraviado a los efectos que marca el artículo 104 del Código Penal que se impugna; sin que la frase genérica $<<$ herederos $>>$ con que se designan pueda estimarse incorrectamente empleada, sino todo lo contrario, porque ni es lógico presumir que sean conocidos individual $\mathrm{y}$ fehacientemente en el momento del fallo penal ni este procedimiento es el adecuado para hacer declaración expresa y nominal de a quiénes alcanza tal carácter ${ }^{34}$.

Igual predicamento se denota en la resolución de 23 de junio de 1956, pues indica que basta con hacer una declaración genérica del derecho a la indemnización a favor de los herederos sin que, como se dijo, fuera necesario precisar en la sentencia quiénes ostentan tal condición, continúan expresado los magistrados españoles:

33 Art. 661 CC: "Los herederos suceden al difunto por el hecho solo de su muerte en todos sus derechos y obligaciones".

34 STS, 2a , de 27-11-1954 (Ponente: Juan García Murga y Mateos, RAJ 1954/2716). En esta causa los hechos acaecieron cuando el procesado conducía un camión, propiedad de otro individuo de quien era dependiente, transportando leña, y permitió que seis individuos subieran al vehículo con tan mala suerte que la carga y los pasajeros se desprendieron en un barranco y como consecuencia falleció uno de ellos. El TS le condenó a penas de seis meses de arresto mayor, 1000 pesetas del multa, retiro del carné de conducción y a una indemnización de 30.000 pesetas a favor de los herederos perjudicados con cargo al responsable civil subsidiario. 
... ha dispuesto el artículo 105 del mencionado Código y su párrafo segundo que es transmisible [la indemnización] a los herederos del que fue perjudicado, y este precepto, tan claro y preciso que no admite posibles interpretaciones que lo desvirtúen, sitúa el derecho a ser indemnizado en aquellas personas que conforme a ley civil deban ser tenidas como sucesoras; y así los Tribunales de lo penal, al hacer ese reconocimiento no precisan, ni está en su propia órbita jurisdiccional hacer declaración alguna atribuyendo tal condición a persona determinada, y menos aun a excluir arbitrariamente a cualesquiera de los que puedan ostentar tal derecho bajo preceptos y apreciaciones fuera de lugar y contrarias a las presunciones de afectos que llevó al legislador a establecer la graduación en el orden sucesorio $a b$ intestato..... ${ }^{35}$.

La jurisprudencia penal, paulatinamente ha experimentado un importante giro, primero "tímidamente" a partir de la sentencia de 24 de mayo de 1960 en la que se reconocía de forma implícita que el derecho a la indemnización de los daños derivados de la privación de la vida no llega a formar parte de la esfera jurídica del causante, ya que la capacidad jurídica del interfecto se había extinguido con la muerte, de tal manera que ningún derecho podía ingresar en su patrimonio (RoIg Torres, 2000, p. 256), dice la sentencia en mención,

... la indemnización no se concede al fallecido con transmisión a sus herederos, sino que a éstos por razón de la muerte violenta de su pariente, concesión que se hace a título personal a los que le suceden y vinculada a que concurra en los mismos la calidad de heredero del interfecto ${ }^{36}$.

Este cambio de dirección se evidenció con una mayor contundencia cuando en determinadas sentencias se les dio prioridad a terceras personas como beneficiarias del monto indemnizatorio, preferentemente sobre herederos de la víctima, se denota así, que el Tribunal empieza a dar prioridad a los perjudicados sobre los herederos cuando ambas circunstancias no se consuman en una misma persona. Ejemplo de esta doctrina se encuentra en la resolución de 19 de mayo

35 STS, 2a , 23-06-1956 (Ponente: Federico Parera Abello, RAJ 1956/2090). En este juicio se condenó al autor del delito de imprudencia temeraria por atropellar con un camión a dos personas, una de las cuales falleció a las pocas horas. El padre y la esposa del fallecido obtuvieron una indemnización de 60.000 pesetas.

36 STS, 2a , de 24-05-1960 (Ponente: Federico Castejón y Martínez de Arizala, RAJ 1960/2510). En este juicio la Audiencia Provincial sancionó al autor de un delito de imprudencia temeraria derivada de un accidente de tráfico mortal. En contra esta sentencia el procesado recurre en casación; el Tribunal estima en parte el recurso y disminuye la tipificación del delito a simple imprudencia antirreglamentaria. 
de 1969 (RAJ 2894) en la que se le otorga una reparación a la concubina del fallecido, con la que mantenía una relación more uxorio y a las dos hijas de 16 y 18 años fruto de esa relación de más de dos décadas. En cambio, se le denegó la indemnización a la esposa de la víctima que legalmente continuaba casada, pero separados de hecho y por sentencia del Tribunal Eclesiástico. El fallo referido literalmente dice,

Que el segundo motivo del recurso [...] denuncia la indebida aplicación del artículo 104 en relación con el 101, ambos del Código Penal, y no puede prosperar, pues tales preceptos no mencionan a los herederos, $\mathrm{y}$ sí a los que sean perjudicados, por tanto, no existe el derecho de la viuda recurrente a percibir indemnización, olvida la amplia facultad de la Sala para fijar las personas y cantidades en que deben ser indemnizadas, y aunque cierto es que la recurrente estaba casada con fallecido señor $Z$., con quien contrajo matrimonio siendo viuda y con hijos, no lo es menos que en tal matrimonio vivían separados de hecho hacía más de veinte años, y que en virtud de Sentencia del Tribunal Eclesiástico del Obispado de Palencia en 14 de junio de 1952, obtuvo la recurrente la separación por adulterio del marido, y aunque tal resolución no haya disuelto el vínculo matrimonial, sí establece una separación de personas y bienes, y en estas circunstancias, sin que conste las obligaciones que le pudieron ser impuestas al señor Z., en ejecución de la sentencia, no aparece el perjuicio material para la recurrente, hoy para su heredero, ni siquiera el moral, después de más de veinte años de separación de hecho y 16 de derecho, sin relación ninguna.

Sin embargo, el viraje más radical de la jurisprudencia de esta Sala Penal se palpa en la Sentencia de 16 de marzo de 1971, que resuelve la demanda de indemnización reclamada por el cónyuge y la hija por el fallecimiento de la esposa y madre respectivamente, víctima de un atropello. Contra la resolución, el demandado interpuso el un recurso de casación alegando, entre otros argumentos, infracción del artículo 105, párrafo segundo del Código Penal, porque las indemnizaciones debieron fijarse a favor de los herederos del interfecto. El recuso fue rechazado y en esta decisión judicial por primera vez se aprecia un intento de unificación de criterios con la jurisprudencia civil, pues se admite el derecho a percibir la indemnización por parte de los perjudicados fueran o no sucesores de fallecido, específicamente dice esta sentencia,

Que tampoco se ha infringido el artículo 105-2. ${ }^{\circ}$ del Cp, pues el art. 101 en su núm., $3 .^{\circ}$ remite el concepto indemnización a la noción de perjui- 
cio de la que son titulares los perjudicados, que si bien de ordinario son los herederos no es rigurosamente imposible el supuesto de que determinados herederos no resulten perjudicados por la muerte de su causante hereditario, siendo distinto el concepto herencial del de perjudicado por el delito como se deduce de los arts. 103 y 104 del Cuerpo legal ... ${ }^{37}$.

Esta sentencia marca un hito dentro de la jurisprudencia penal porque, a partir de ella, la Sala penal ha negado a los herederos el derecho indemnizatorio en virtud de la cualidad de sucesores del finado. Esta nueva orientación se afianza con la resolución del Tribunal Supremo de 10 de febrero de 1972 que admite el recurso de casación y se concede una indemnización a una señorita, con preferencia sobre los herederos, por la muerte en accidente de una mujer,

... y aunque esta Sala ha venido proclamando como principio general que las consecuencias indemnizatorias de una muerte suelen ir unidas a la calidad de herederos, también ha declarado en sentencia de 16 de marzo 1971 (R. 945) [por error cita el repertorio no 945 cuando en realidad es el $n^{\circ}$ 943], ser distinto el concepto herencial del perjudicado por el delito según se desprende de los arts. 103 y 104 del Código Penal. Aplicando dicha doctrina al caso ahora debatido, no haberse causado ningún perjuicio a los herederos forzosos de la víctima, en el supuesto de que los haya, y por el contrario, sí se han irrogados a las personas que vivían con la anciana fallecida desde hace muchos años, atendiéndola con solícito cuidado, unidas por indelebles vínculos de amistad, mucho más fuertes a los correspondientes a un parentesco sin relación alguna... ${ }^{38}$.

Esta corriente unificadora de la doctrina del Tribunal Supremo se patentiza en posteriores decisiones como la de 13 de junio de 1981:

Las personas a quienes corresponde la indemnización por muerte ocurrida con motivo de un accidente de circulación son los perjudicados y no los herederos, lo cual se funda en la aplicación de la normativa vigente en nuestro Ordenamiento Civil, ya que, según ella, únicamente los vivos son sujetos capaces de adquirir derechos y únicamente pueden trans-

37 STS, 2a , de 16-03-1971 (Ponente: Jesús Sáez Jiménez, RAJ 1971/943).

Artículo 101 del anterior Código Penal español:

La responsabilidad establecida en el capítulo II, título II de este libro, comprende:

$1 .^{\circ}$ La restitución.

2. ${ }^{\circ}$ La reparación del daño causado.

3. ${ }^{\circ}$ La indemnización de perjuicios.

STS, 2a de 10-02-1972 (Ponente: Jesús Sáez Jiménez, RAJ 1972/585). 
mitirse por vía hereditaria aquellos que, al tiempo del fallecimiento del causante, se hallasen integrando su patrimonio.... ${ }^{39}$

Más reciente, la sentencia anteriormente citada de esta Sala penal de 15-041988 (RAJ 1988/2777), recalca esta última tendencia y expone

...que es aplicable, a estos casos, el art. 104 del CP -familia- y no el 105 del mismo -herederos- porque al fallecer una persona como consecuencia o resultado de un delito, surge la obligación de indemnizar, pero no por virtud del fenómeno sucesorio, puesto que el difunto nada llegó, en vida, a adquirir que, integrando en su patrimonio, fuera luego objeto de transmisión mortis causa, sino, sencillamente, porque dándose los factores antes enumerados, gastos funerarios, desamparo económico, daño moral en todo o en parte, en los próximos parientes, a ellos, como consecuencia del fallecimientos de la víctima de la infracción penal, corresponde ex novo y por derecho propio, y no por virtud de la sucesión, el derecho de indemnización. Dicho de otra forma, que el extinto no puede adquirir la titularidad de la acción dirigida a exigir la responsabilidad civil y, al no poder adquirir, no puede transmitirla a sus herederos; para que la acción de restitución, reparación e indemnización se pueda transmitir a los herederos, según el artículo 105 del $\mathrm{CP}$-segundo párrafo- sería indispensable que el causante hubiera, previamente a su fallecimiento, adquirido la titularidad de la mentada acción, lo que resulta absolutamente imposible, porque la misma ha nacido precisamente en virtud de su muerte ${ }^{40}$.

Sintetizando la corriente unitaria de las dos Salas del Tribunal Supremo, se puede afirmar que los magistrados consideran que una vez acaecido de forma inmediata el fallecimiento de la persona, se extingue su capacidad jurídica, y por esta razón ningún derecho indemnizatorio puede ingresar en su patrimonio y mucho menos ser transmitido a sus herederos.

39 STS, 2a , 13-06-1981, (Ponente: Manuel García Miguel, RAJ 2652). En este caso el TS condena al autor de un delito de imprudencia temeraria. Los hechos sucedieron cuando un turismo se paró al lado derecho de la carretera, un primer camión que circulaba detrás también se detuvo, pero un segundo camión que viajaba a exceso de velocidad, con una carga de cerdos abierto en canal sin guardar la debida distancia, no pudo frenar a tiempo, invadió completamente el carril contrario y terminó colisionando con una furgoneta que venía en esa otra dirección con luctuosas consecuencias.

Sentencia referida en p. 9. 


\section{Antagonismo doctrinal}

Comparte esta postura de la jurisprudencia, entre otros, el jurista Gómez ORBANEJA ( I 949), quien expresa, "La acción civil no se transmite a los herederos [...] Ofendido por el delito es el difunto; perjudicado podrá serlo el heredero, legítimo o testamentario, pero iure proprio, en cuanto haya experimentado un perjuicio, patrimonial o moral...” (p. 197). También participa de esta doctrina el magistrado Soтo Nieto ( I970), para quien "Los parientes o herederos más que en representación del causante, obran iure proprio, como verdaderos titulares de la acción, aludiendo a los perjuicios materiales y morales que les han sido provocados por la muerte de la víctima” ( p. 86). En el mismo sentido, explica el docente O'CaLlaghan ( 1987 ),

En el instante mismo del daño -muerte- se produce la extinción de la personalidad, por lo cual no puede llegar a adquirir ningún derecho por la propia pérdida de la vida, como el de la reparación del daño. Por tanto, tal derecho no llega a entrar en su patrimonio e integrar la herencia, sino que lo tienen como perjudicados, los parientes o allegados, sin importar si son herederos..."(p.322).

Los civilistas Martín Villa \& Blanco ( I992) manifiestan que “...no cabe la sucesión en el derecho a obtener un resarcimiento a consecuencia de un daño moral padecido por el causante" (p.664), sin embargo, estos autores admiten una excepción de este principio en situaciones en que el daño moral causado al finado transcendiera de forma indirecta a las personas de los herederos, como es el caso de los delitos de calumnia e injuria en los que "la acción puede ser ejercitada por los familiares" (p. 664).

Para la Doctora Domínguez Hidalgo (200ob) admitir la transmisión de la acción de reparación del daño moral "implicaría concebir la indemnización como sanción o pena y ni siquiera a favor de la víctima, y un enriquecimiento sin justificación alguna de los herederos” (p. 735).

De acuerdo con el profesor Medina CRespo (2000), "Es el título perjudicial y no el herencial el que desencadena el resarcimiento por causa de muerte” (p. 72). Según el catedrático Albaladejo (2004), entre los derechos que nacen en cabeza del que los adquiere, aunque con ocasión de la muerte de una persona, están "las indemnizaciones que por daño moral o material son debidas a la persona que lo sufre a causa de la muerte de otra" ( p.15). 
En la doctrina argentina destacamos al jurista Orgaz quien afirma que:

Tampoco pasa la acción, por causa de muerte, a los herederos del titular (art. 1195): en el homicidio, por ejemplo, los miembros de la familia del muerto solo pueden pretender la reparación del daño moral que personalmente han sufrido, y no la del supuesto daño del muerto, del que ellos serían herederos, salvo si la víctima hubiese deducido en vida la acción" (p. 219) ${ }^{41}$.

Debemos señalar que al desligar el concepto de reparación del concepto de herederos en caso de muerte, se amplía el panorama de los sujetos beneficiarios de la indemnización, abarcando a todos los perjudicados sean herederos o no, siempre que demuestren el pesar o desconsuelo porque con el fallecimiento del occiso se rompen los lazos de convivencia y afecto.

Empero, para otro sector doctrinal el Derecho a la reparación del daño moral se transmite vía iure hereditario; encabeza este grupo de autores, el maestro DE Castro y Bravo (1956), quien apunta que "el daño se produce a la persona que vive; a ella se le quita la vida o se le da la muerte. No es la muerte (consecuencia), sino el acto que la produce, el que origina la responsabilidad del culpable" (p. $486)^{42}$. Esta aseveración es sutilmente cuestionada por el jurista SÁNCHEz VÁz-

41 E1 Código Civil argentino se adhiere a esta línea de pensamiento puesto que estipula en el art. 1078: "La acción por indemnización por daño moral solo competerá al damnificado directo; si del hecho hubiere resultado la muerte de la víctima, únicamente tendrán acción los herederos forzosos”. De este precepto se entiende que al no haber transmisibilidad de la acción, los herederos forzosos solo tienen una legitimación iure proprio.

42 Este debate es relacionado en la STS de 12 de mayo de 1990, Sala Segunda de lo penal, Ponente: Ramón Montero Fernández Cid, que establece:

Cierto es que una larga y continuada serie de decisiones de esta Sala y de la Primera de este mismo Tribunal han venido resolviendo genéricamente el difícil tema de la naturaleza jurídica de la indemnización por causa de muerte en el sentido de estimar la legitimación para percibirla no a los herederos en cuanto tales, sino a los perjudicados por la muerte. Se ha dicho así, por ejemplo, entre muchas, en la Sentencia de 20 de octubre de 1986, que «solo los vivos son capaces de adquirir derechos y únicamente pueden transmitirlos por vía hereditaria aquellos que al fallecimiento del causante se hallasen integrando su patrimonio, condición que no concurre en la indemnización por causa de muerte, pues al ser la muerte la que genera el derecho a la indemnización aparece evidente que este derecho lo adquieren los perjudicados originariamente y no por vía derivativa». En la Sentencia de 21 de diciembre de 1987 , se expresa que estos perjuicios materiales y morales corresponden iure propio y no iure hereditario, y finalmente, la Sentencia de 15 de abril de 1988, con cita de varias resoluciones anteriores, ratifica que es aplicable el art. 104, que se refiere a «familia» y no el 105 del mismo Código Penal, que alude a «herederos», expresando que «al fallecer una persona como consecuencia de un delito surge la obligación de indemnizar, pero no por virtud del fenómeno sucesorio, puesto que el difunto nada llegó en vida a adquirir, que, integrado en su patrimonio, fuera luego objeto de transmisión mortis causa». La doctrina precedente ha sido ya mucho criticada por la más autorizada doctrina científica civil española, al indicar que existía así un sofisma al no tenerse en cuenta, que el daño se produce a la persona 
QUEZ (I973), al señalar que "la responsabilidad civil no surge sin un resultado. Es la muerte la determinante de la privación del bien (vida), y la indemnización de daños y perjuicios no se otorga sin ese resultado" (p. 24) ${ }^{43}$, o, como lo interpreta el especialista en daño corporal Medina Crespo (2000), "la responsabilidad civil surge efectivamente del acto, pero no surge cuando falta la consecuencia perjudicial” (p. 98). Frente a esta disyuntiva, aquí se responde que así_como_al nasciturus, si nace con vida, sus derechos se retrotraen al momento de su concepción, de igual manera, al consumarse la muerte de la víctima, el nacimiento de su derecho de indemnización se retrotrae al momento en que se produce el acto que posteriormente provocó el desenlace fatal. Por lo tanto, este derecho ingresa a su patrimonio y es perfectamente transferible. No hay que olvidar que, como se ha señalado, la acción vía iure hereditario data de la fecha del accidente, pero más preciso sería decir que data desde el momento en que se inició la ejecución del acto que a posteriori desencadena las consecuencias mortales.

También se adscriben a esta línea de pensamiento proclive a la legitimación iure hereditatis el jurista Gullón Ballesteros ( 1 972, p. 498). En el mismo sentido dicen los penalistas Antón Oneca \& Rodríguez Muñoz (i 949),

Resulta paradójico que en un homicidio sean los familiares perjudicados y no el que pierde su vida. Ésta no solo consta de presente y pasado, sino de porvenir; es continuidad, sucesión, perspectiva, y ese futuro que se espera valora el momento presente. De todo este conjunto de posibilidades queda disminuida la víctima en el último instante de su vida, sin que importe se dé o no cuenta -que esto tampoco puede nunca precisarse con certeza-, pues el daño resarcible no tiene por qué ser consciente. En definitiva, el perjuicio del homicidio está en la privación de la vida, y de la vida no se priva nunca a un muerto. (pp. 625-626).

Se suscriben a este lineamiento los juristas Mazeaud-Tunc ( I963) con la siguiente argumentación,

que vive, pues es a ella que se quita la vida o se le da muerte, por lo que no es el hecho de la muerte (consecuencia), sino el acto que la produce, el que origina la responsabilidad del culpable; con lo que el hecho causante se produce viviendo la víctima. Es, sin embargo, la jurisprudencialmente establecida y tal interpretación debe ser mantenida en aras al valor de certeza y seguridad jurídicas establecido en el art. 9. de la Constitución. Documento recuperado el 8 de noviembre de 2013, de

http://app.vlex.com/\#search/content_type:2/da\%C3\%B1o+moral+transmisi\%C3\%B3n+iure+proprio+iure+hereditario/vid/209111151

43 Es decir, que cuando nace la responsabilidad civil (con la muerte) ningún derecho puede adquirir la víctima. 
El daño se sufre necesariamente por la víctima antes de su muerte. Por rápida que ésta haya sido, entre ella y los golpes asestados ha transcurrido forzosamente, al menos, un instante de razón. Obligatoriamente, los golpes han precedido a la muerte. En ese instante, por breve que haya sido, en que la víctima ya alcanzada no había muerte aún, en ese instante en que su patrimonio existía todavía, se origina el crédito de indemnización; por lo tanto, los herederos lo encuentran en la sucesión (p. 541).

En este mismo sentido se expresa el profesor Díez-Picazo (r 973), “... en el caso de demanda del heredero el daño consiste en el hecho mismo de la muerte..." (p. 300). Según el magistrado SANTos BRIz (I 993), "La acción por esta pérdida [de la vida] debe ser transmisible a los herederos...” (p. 362). Se adscribe a esta línea de pensamiento la maestra Vicente Domingo (i 994),

... la muerte es un daño, incluso, el más grave de todos los que se puede sufrir y que es reparable; que la acción para el resarcimiento entra en el patrimonio de la víctima en el mismo instante en el que sufre el daño y se transmite por consiguiente mortis causa a los herederos, igual que los demás bienes de carácter patrimonial que hubieran pertenecido al de cujus ( p. 243).

Según el jurista Montés Penadés ( I 996),

$\mathrm{Al}$ imponerse la tesis que excluye del acervo patrimonial del agraviado la pretensión resarcitoria y con ello de su herencia, se ha oscurecido por confusión la distinción entre este daño [la muerte] y el que puede estimarse irrogado a los parientes o terceros como un menoscabo concreto e individualizado de un bien material o moral (p. 606).

Sobre este tema expresan los tratadistas Díez-PiCazo y Gullón, "Creemos que la pérdida de la vida por culpa o negligencia ajena es un daño que se infiere a la persona misma, consistente en acortársela, en lo prematuro de la defunción" (p. 547).

De acuerdo con los civilistas Lacruz Berdejo, J. L., Sancho Rebudilla, F. de A.; Luna Serrano, A., Delgado Echeverría, F., Rivero Hernández, F., y Rams Albesa, J. (2002, p. 466),

Alegar que el heredero no ha sufrido la privación de la vida, y que el difunto deja de existir cuando se produce tal privación, es un sofisma. Hay 
ofensa a la persona, con el daño supremo de la muerte (acortamiento de la existencia); hay (por definición) acto culposo, del que nace la responsabilidad eventual, que se actualiza por la presencia del perjuicio; éste debe ser resarcido, y el heredero es el titular por excelencia del resarcimiento debido al causante, como lo es del daño que proceda de agresión contra la personalidad pretérita del mismo (injuria o calumnia).

El profesor Pantaleón Prieto (i989) da a entender que la aceptación de la legitimación iure sucessionis es hija del facilismo, pues en estos casos de indemnización por causa de muerte, adoptar esta vía supone un menor esfuerzo para los fiscales y audiencias en comparación con el que tendrían que llevar a cabo de elegir la legitimación iure propio porque "no hay que investigar quiénes son, y en qué medida cada uno, los verdaderos perjudicados por la muerte de la víctima" (p. 617) ${ }^{44}$.

Esta disquisición conlleva a otro punto de consideración; hasta ahora se ha examinado el supuesto en el que la víctima muere de forma inmediata como consecuencia del hecho dañoso, pero cabe suponer el más que probable caso en el que transcurra un considerable tiempo entre el acontecimiento del accidente y el fallecimiento de la víctima, como consecuencia de aquel hecho. Bajo estas circunstancias, la mayor parte de la doctrina, incluyendo el sector renuente a concebir la transmisión hereditaria de la acción de reparación en casos de muerte instantánea, es conteste a la hora de admitir la transmisión de esta acción, cuando el fallecimiento no se produce de forma inmediata. Sin embargo, de forma paradójica, esto juega en contra de esta línea doctrinaria reacia a la legitimación iure hereditaria; pues, como bien lo señala el civilista Álvarez Vigaray (ig66), “... el carácter instantáneo o no de la muerte es una diferencia accidental que no justifica un diverso régimen jurídico...” (p. 109).

Un aspecto estrechamente vinculado al tema de la transmisión del daño moral, consiste en la composición del proceso en caso de pluralidad de víctimas por

44 Así se expresa la ya citada STS, 2a de 15-04-1988 (RAJ 1988/2777), "Por ello, los tribunales de instancia, desechando toda inclinación a la comodidad, deben declarar en sus sentencias, nominatum y en cuanto sea posible, las personas a las que debe pagarse o satisfacer la indemnización, así como la cuantía de la misma y la suma, cantidad o cuota que corresponde a cada uno de los beneficiarios.

'En este caso, la Audiencia de origen, desconociendo o no acatando esta constante doctrina jurisprudencial, con singular apatía y siguiendo la ley de mínimo esfuerzo y no deseando asumir 'la ingrata e ímproba tarea' de indagar quiénes eran los parientes más próximos a la interfecta, fijó, prudencial y certeramente, la condigna indemnización, pero disponiendo el pago de la misma a favor de los herederos de la mentada difunta, pese a que muy poco esfuerzo le hubiera costado concretar la identidad de los mismos y la cuota que corresponde a cada uno de ellos...”. 
repercusión, se comparte la opinión de que en estas circunstancias el litisconsorcio más adecuado es el facultativo, respetando las posibles acciones aisladas de las víctimas indirectas que no se adhieran a la demanda colectiva (Sobre este tópico consultar al magistrado Alonso Prieto (i 972, p. 429 y ss) ${ }^{45}$. Así, en este mismo sentido se expresa el jurista MARín López (I 997),

La pretensión indemnizatoria de cada perjudicado es independiente de la de los restantes, y corre una suerte propia que no necesariamente ha de ser compartida con la de sus congéneres. [...] La independencia entre los derechos indemnizatorios de los diversos perjudicados explica la ausencia de litisconsorcio activo necesario, entre aquellos" (pp. 56-57).

Dentro de toda esta pugna, parece que va prevaleciendo la doctrina de la titulación por derecho propio, porque incluso ha recibido en España una consagración legislativa a través de la Tabla I de la Ley 30/95 que se acopla de una manera literal al criterio de que la indemnización por causa de muerte se genera iure proprio y no iure hereditatis ${ }^{46}$.

Pese a ello, se quiere recalcar que de acuerdo con el criterio aquí defendido, no se encuentra ningún obstáculo para que en circunstancias de indemnización por causa de muerte, los perjudicados (sean herederos o no), puedan legitimar su pretensión resarcitoria iure proprio y, en el frecuente caso en que ambas titulaciones coincidan en las mismas personas, es decir, igual sean herederos y perjudicados, nada impide que la acción de reparación pueda ser ejercitada en virtud de ese doble carácter, tanto como perjudicados directos, como por herederos del derecho a reparación del perjuicio sufrido por la víctima mortal. Para ello no obsta o, mejor dicho, carece totalmente de importancia el elemento circunstancial y accidental como la inmediatez o no del fallecimiento. Como dice el profesor De Cupis (I975),

45 Esta doctrina es confirmada por la SAP de Asturias de 12-03-1992 (AC 1992, 508) que dice, "ni establece el ordenamiento jurídico la forzosa comparecencia de todos los posibles perjudicados en procedimiento para la reclamación de indemnización nacida por culpa extracontractual [...] ni lo exige la relación jurídico-material, ya que la pretendida inescindibilidad de la resolución es más aparente que real, puesto que la eficacia de la cosa juzgada de la sentencia dictada respecto de algunos perjudicados [...] no se produce, haciendo posible la ulterior reclamación de cualquier perjudicado no indemnizado contra quien lo haya sido por vía judicial, o respecto de la entidad aseguradora por la diferencia entre lo concedido y el límite legalmente establecido". Sentencia citada y comentada por J. J. MARÍN LÓPEZ (1997, p. 57).

46 Ley 30/95, "Ley de Ordenación y Supervisión del Seguro Privado" (publicada en el BOE de 9 de noviembre de 1995). 
En consecuencia existe un doble título de resarcimiento por la muerte de una persona: De una parte el daño sufrido por el titular del bien en que consiste la vida; de otra el experimentado por los familiares que sobreviven a la lesión de su interés como parientes. (p. 665) ${ }^{47}$.

\section{Igual postura sostiene el magistrado SANTos Briz (I993) en los siguientes tér- minos,}

Con todo, no cabe negar la posición de los reclamantes, que aun sin demostrar ser herederos, pueden en virtud de su derecho originario de perjudicados, obtener indemnización. Tal vez se imponga la solución intermedia de reconocer una doble cualidad a los reclamantes: como perjudicados iure proprio y como herederos de la víctima... (p. 363).

La fundamentación de esta concepción es proporcionada por diversas consideraciones, entre las que destacan, por ejemplo, que resulta chocante a la idea de justicia que mientras cualquier mínima lesión sea objeto de indemnización, el atentado al más excelso de los bienes que un ser humano posee (la propia vida) pueda quedar sin compensación por elucubraciones tan artificiosas como la simultaneidad o no entre el accidente y el deceso del finado. En efecto, se afirma que en estricto sentido científico no existe la muerte instantánea, siempre hay un intervalo de tiempo entre la lesión y la muerte; como dice la profesora VICENTE Domingo (I 994).

47 Antiguamente el Tribunal Supremo español admitía el ejercicio conjunto de éstas dos acciones en sentencias, antes comentadas, como la ya referida resolución de 08-01-1946, que dice en la parte resolutiva: “... y en su consecuencia debemos condenar y condenamos a la Compañía de los Ferrocarriles mencionada, a que pague la suma de 31.450 ptas., en concepto de reparación de daños e indemnización conjuntamente a las accionantes [...], por su propio derecho y como viuda y madre respectivamente del siniestrado J. B. J. y herederas únicas y universales abintestato del mismo...”. En la también citada STS, 1a, 17-02-1956 no se dilucida el tema de la transmisibilidad del daño moral sufrido por la víctima inicial, pero recalca la necesidad de "fijar aunque sea elementalmente casos y conceptos, distinguiendo al efecto, con relación al difunto, por una parte, unos perjuicios de carácter patrimonial, como los gastos de entierro y funeral, que constituyen cargas hereditarias (arts. 840, 902, 903 del expresado Código) y cuando no se trate de muerte instantánea, los de clínica y farmacia, impedimento para el trabajo, etc., que dan nacimiento a una acción de indemnización de la de aquellos a favor de los herederos, y la de éstos a favor del causante, pero transmisible a sus derechohabientes; y por otra, el daño moral constituido por dolor psicofísico que la lesión mortal hace sufrir a la víctima, que aunque compensable también crematísticamente -pecunia doloris- en la forma prudencial en que puede serlo, respecto al cual sigue constituyendo aun en la doctrina de la jurisprudencia un problema, el de su transmisibilidad de la acción competente a los herederos, sobre todo en el supuesto de muerte instantánea, supuesto éste que, entendido simultáneo de la lesión, no todos admiten. Pero al lado de estos perjuicios, y con absoluta independencia de los mismos, surgen, además, los daños de carácter moral, que experimentan también los parientes más allegados de la víctima, lesionados en sus afecciones más íntimas y legítimas e indemnizables también en dinero". 
... la muerte instantánea, no solo es un expediente artificioso y accidental sino que es una ficción de eficacia exclusivamente retórica, pero que no responde a la realidad científica que se ha plasmado y que el iter, por breve que sea, muestra que no hay simultaneidad entre los dos momentos, no solo físicos sino también jurídicos (pp. 243-244).

Además, no hay que obviar que no existe ninguna normativa que prohíba de forma tajante la transmisión del daño no patrimonial sufrido por la víctima mortal a sus herederos. Es más, podemos afirmar que no solamente no existe una norma que impida la transmisión del daño moral, sino que, más bien, el artículo $1871 \mathrm{C}$ estipula que "Todos los derechos adquiridos en virtud de una obligación son transmisibles con sujeción a las leyes, si no se hubiere pactado lo contrario (precepto copiado del art 1112 del Código civil español). Además, como hemos dicho, lo que origina la responsabilidad no es la muerte en sí, sino el acto que desencadena el desenlace fatal. Este acto, obviamente, es anterior a la muerte del interfecto y por eso entra a su caudal hereditario y es transmitido a sus herederos. El catedrático Pantaleón Prieto (i 983), con respecto al referido art. 1112, dice que "podría contestarse que dicho precepto se aplica únicamente a las obligaciones derivadas de contrato, como lo prueba su inciso final: <<si no se hubiere pactado lo contrario >>" (p. 1574). Frente a esto, se puede decir que de conformidad con la STS, 1a, de 26-01-1984 (Ponente: Jaime Santos Briz, RAJ 1984/386) “... la regla general es la aplicación preferente de los preceptos de responsabilidad contractual”. Además, los artículos de ambas categorías de responsabilidad civil se pueden complementar recíprocamente; en el derecho comparado se encuentran varios casos que corroboran esta aseveración ${ }^{48}$. En Argentina, el profesor OrGaz, refiriéndose al mismo tema dice que

48 Por ejemplo, el anterior Código Civil portugués de 1867 que disponía en su artículo 2.393: "La responsabilidad proveniente de la no ejecución de los contratos se regirá por las disposiciones de los artículos 702 y siguientes; la responsabilidad que derive de cualquiera otras obligaciones, se regirá por los mismos principios, en todo aquello a que éstos fueren aplicables". De similar manera se expresa el Código suizo de las obligaciones en el apartado $3^{\circ}$ del artículo 93 que dice: "Las reglas relativas a la responsabilidad derivada de actos ilícitos se aplican por analogía a los efectos de la culpa contractual". Por su parte, el artículo 294 del Código Civil cubano estipula: "las normas relativas a la responsabilidad por actos ilícitos se aplican, en lo pertinente, en los casos de incumplimiento de las obligaciones". La sentencia antes relacionada atañe a un caso en que la parte accionante demandó a una empresa municipal de agua y alcantarillado por unas filtraciones de aguas fecales que produjeron ciertos daños de menor cuantía. La parte demandada alegó la prescripción de un año contemplada para la responsabilidad civil extracontractual en el sistema español, el TS desestimó el recurso con el argumento "que aunque no haya obligación derivada de contrato, si hay otra relación jurídica que concede un medio específico para el resarcimiento, ello excluye la aplicación del artículo 1902 CC" porque, como se dijo, por lo general se aplica con preferencia al normas de la responsabilidad contractual. Y por lo tanto el plazo de prescripción quedó fijado en 15 años. 
Hay, así, dos legislaciones separadas y autónomas para ambos campos de la responsabilidad, la contractual y la extracontractual. Pero como la situación fundamental es sustancialmente la misma, hay también una intercomunicación de principios o reglas de la una a la otra, en lo no previsto expresamente por cada una, en virtud de la analogía ( p. 12).

La doctrina reacia a la transmisión de la reparación del daño moral se desvanece sobre todo cuando existe el precedente de admitir la transmisión una vez incoada la demanda antes del fallecimiento del perjudicado directo (MARTín Casal, M., Ribot R., \& Solé, J., 200I, p. 200)49. Es decir, no se entiende por qué en este caso nadie asimila las objeciones, por ejemplo, de que el daño moral es personalísimo o que es inmoral que alguien se beneficie del daño no patrimonial ajeno, y en cambio, estos cuestionamientos sí tienen validez cuando el demandante no pudo interponer su acción de reparación por causas ajenas a su voluntad, como su deceso inmediato producto del evento dañoso. No se puede medir con doble rasero situaciones jurídicas que en su esencia son iguales, pues es el mismo daño moral el que se manifiesta con o sin interposición de la pretensión resarcitoria por la víctima directa. Propugnar que la reparación del daño extrapatrimonial solo puede ser transmitida a los sucesores de la víctima inicial si éste había deducido la acción de indemnización antes de su fallecimiento, es tan absurdo como admitir que el derecho nace de la acción, cuando en realidad, la acción surge del derecho.

Argumentando siempre a favor de esta doble titulación, mediante la cual los herederos y/o perjudicados pueden accionar en virtud del iure proprio y el iure hereditatis, se opina que esta postura es la más acorde al principio pro damnato que establece una interpretación de las normas de la responsabilidad civil en el sentido que sea más favorable al perjudicado o víctima del daño.

Por otra parte, carece de consistencia jurídica que mientras el daño moral que atenta contra los derechos de autor pueda ser transmitido a los herederos de acuerdo con el art. 21 de la Ley $\mathrm{N}^{\circ} 312 / 1999^{50}$, en cambio, se impida la suce-

49 M. MARTÍN CASAL, J. RIBOT \& J. Solé, “Non pecuniary loss under Spanish low”, en Damage for non-pecuniary loss in a comparative perspective, dir. por W. V. H. Rogers \& H. Koziol, SpringerWienNewYork, Viena, 2001, n² 28, p. 200.

50 Ley N$^{\circ} 312$, Ley de derechos de autor y derechos conexos, publicada en La Gaceta, Diario Oficial $\mathrm{N}^{\circ}$ 166 y 167, del 31 del Agosto y 1 de Septiembre de 1999. Art. 21: “Al fallecer el autor se transmite a sus herederos el ejercicio de los derechos contenidos en el Artículo 19 de la presente Ley, sin límite de tiempo.

'No obstante, el autor mediante testamento, podrá confiar el ejercicio de los derechos mencionados en el párrafo anterior a cualquier persona natural o jurídica. 
sión por causa de muerte del daño no patrimonial causado al interfecto. A igual conclusión se arriba si se toma en cuenta que en el Derecho comparado las agresiones contra el honor, intimidad e imagen, el daño extrapatrimonial causado a la víctima inmediata puede ser transmitido a sus sucesore ${ }^{51}$. Siendo un mismo daño moral no se entiende ¿por qué en ciertas circunstancias puede ser transmitido y en cambio en otras no?.

Cuando esta doble titulación (herederos y perjudicados) coincida en las mismas personas, se deben demostrar ambas cualidades para poder beneficiarse de las partidas indemnizatorias. Es decir, no basta ser familiar (heredero) del interfecto para tener derecho a recibir la transmisión del daño moral padecido por él, sino que es necesario que demuestre su calidad de perjudicado. De esta manera se impide que los familiares lejanos o, los que siendo cercanos, no mantenían ningún vínculo con la víctima mortal o, incluso, acreedores o el mismo Estado, puedan percibir la reparación del daño moral padecido por el causante.

Una seria debilidad que presenta esta postura pertenece al terreno procesal, porque, efectivamente, cuando se produce el suceso mortal y se interpone la demanda de indemnización, es probable que no se acredite desde un inicio la condición de heredero, no obstante, en el petitum, se puede dejar constar esa situación e introducir ciertos documentos como testamento o actas de nacimiento que hagan presumir la condición de presuntos herederos, y luego, comprometerse a presentar con posterioridad la correspondiente sentencia en la que se declare la condición de sucesores del causante. $\mathrm{Y}$, si en primera instancia no se puede demostrar la cualidad de heredero, es muy difícil imaginar que en la instancia subsiguiente no se pueda enmendar ese defecto. Además, si el acontecimiento que provoca la muerte de la víctima directa es constitutivo de ilícito penal, los herederos y/o perjudicados indirectos o víctimas por rebote pueden reservarse la

'A falta de herederos o de las personas designadas por el autor conforme se mencionan en el párrafo precedente, se procederá según lo dispuesto en el Título VIII, Artículos 1008 y siguientes del Código Civil "De la Distribución de la Herencia >, en cuanto a los derechos mencionados en los numerales 1 y 2 del Artículo 19 de la presente Ley".

Consultar también los arts. 14 y 15 de la, Ley N ${ }^{\circ}$ 1/1996, Ley de Propiedad Intelectual [de España] publicada en el BOE No 97, de 22 abril de 1996.

51 Ley Orgánica 1/1982 de protección civil del derecho al honor, a la intimidad personal y familiar y a la propia imagen, publicada en el BOE $n^{\circ} 115$, de 14 de mayo de 1982 En este sentido verificar los arts. 4, 5 y especialmente el 6.1 de la Ley Orgánica 1/82 de 5 de mayo de 1982, dice este último precepto: "Cuando el titular del derecho lesionado fallezca sin haber podido ejercitar por sí o por su representante legal las acciones previstas en esta ley, por las circunstancias en que la lesión se produjo, las referidas acciones podrán ejercitarse por las personas señaladas en el art. 4. ${ }^{\circ}$ [cónyuges, ascendientes, descendientes y hermanos de la persona fallecida]. Sobre este tema expresan los juristas MAZEAUD-TUNC (1963), "Por ejemplo, los herederos podrán perseguir las difamaciones de que haya sido víctima su causante antes de su muerte y de las que no había pedido reparación” (p. 538). 
acción civil para que, mientras se tramite el juicio criminal, puedan ellos gestionar el proceso de sucesión de tal manera que cuando se interponga la demanda civil, se pueda demostrar tal titulación ${ }^{52}$. No obstante, aun en el caso de que no se demuestre la cualidad de heredero, el catedrático Vattier Fuenzalida(i 990, p. 2083) explica que se ha propuesto que debe estimarse la indemnización por ser una exigencia que se deriva del principio iura novit curia. En este sentido explica el magistrado García Hirschfeld (i 979, p. 1035),

El derecho indemnizatorio no se identifica al derecho hereditario; y, por consiguiente, el que como heredero reclame una indemnización y demuestre el perjuicio, debe considerase legitimado aunque no acredite su condición de heredero, pues aducido el <<petitum >> (indemnización) y el fundamento de su pretensión (perjuicio), la norma jurídica aplicable puede ser invocada por el juez, en virtud del principio <<iura novit curia >>.

Por otra parte, aunque de manera explícita los tribunales se decanten por la legitimación iure proprio, en la praxis judicial existen ciertos comportamientos que hacen dudar de la firmeza de tal resolución. Buena prueba de ello consiste, en que, por ejemplo, la Sala de lo civil del Tribunal Supremo español en ningún caso ha rechazado una demanda indemnizatoria basada en la legitimación iure hereditatis. Así lo destaca el profesor Pantaleón Prieto (i 989),

Conviene mencionar con todo que la Sala que nos ocupa [la civil] no ha rechazado nunca pretensiones indemnizatorias por causa de muerte por el solo hecho de que la indemnización se solicitase en general para los herederos del fallecido, en vez de particularmente para cada uno de los personalmente perjudicados por su muerte: lo ha considerado un puro error formal intranscendente (p. 640).

Es más, se ha visto que, incluso admitiendo la tesis de legitimación iure proprio, los órganos de justicia siguen concediendo indemnizaciones en globo, por esta razón cierto autor afirma que se genera la duda acerca de si el correcto reparto no será el de las respectivas cuotas en la herencia del difunto (Pantaleón Prieto, I 989, p. 643). Esta observación también es señalada por el jurista MARín LóPEZ (1997), "Conviene subrayar que, pese a la rotundidad con que la jurisprudencia

52 Art.114 del CP de Nicaragua: "La ejecución de un hecho descrito por la ley como delito o falta obliga a reparar, en los términos previstos en las leyes, los daños y perjuicios por él causados. El procedimiento para determinar la responsabilidad civil en sede penal es el dispuesto por el Código Procesal Penal. El perjudicado podrá optar, en todo caso, por exigir la responsabilidad civil ante la jurisdicción civil”. 
afirma la independencia de las condiciones de heredero y perjudicado, los tribunales frecuentemente se dejan llevar por la aplicación en sede de indemnización de principios típicamente sucesorios" (p. 52).

\section{V.Transmisibilidad del derecho a la reparación del daño moral por acto entre vivos (inter vivos)}

La doctrina reacia a esta transmisibilidad argumenta que en lo concerniente a la reparación del daño moral, al ser un derecho personalísimo, no cabe la cesión del mismo.

Por el contrario, para fundamentarla la transmisibilidad inter vivos del derecho a la reparación del daño moral, los partidarios de esta tesis, recurren al mismo argumento empleado en la justificación de la sucesión del derecho a indemnización del mismo perjuicio por causa de muerte, en el sentido de que si bien el derecho afectado tiene un sustrato extrapatrimonial, el derecho a su reparación tiene por objeto una prestación pecuniaria de carácter patrimonial susceptible de transmisión (De Cupis, i 975, p. 662; Scognamiglio, i 957, pp. 324 y ss y 1962, pp. 141 y ss; Pizarro, 2000, pp. 254-255).

Para el profesor García López (I 990), el elemento básico para despejar esta incógnita consiste determinar la finalidad del derecho a la indemnización del daño moral. Aunque está de acuerdo con los autores que señalan que no hay que confundir el contenido personalísimo del derecho con la forma que éste adopta de pretensión resarcitoria, afirma que "el contenido patrimonial de un derecho no determina necesariamente el carácter transmisible del mismo" el equívoco consiste en "atribuir a la patrimonialidad la consecuencia necesaria de la transmisibilidad" y cita ejemplos de derecho patrimoniales intransmisibles como los de uso y habitación y el derecho a percibir alimentos (p. 194 $)^{53}$.

Para este autor, tampoco vale argüir que como no existe ninguna norma que prohíba la sucesión de los derechos extrapatrimoniales, se debe admitir su transmisión. Declara que se debe descartar este razonamiento porque "la omisión legal no es indicativa, en este caso, de una voluntad positiva en orden a la transmisibilidad de este derecho" (p. 194).

53 Art. 1548 C: "Los derechos de uso y habitación no se pueden enajenar, arrendar ni traspasar a otro por ninguna clase de títulos". Art. 13.1 de la Ley $\mathrm{N}^{\circ} 143$, Ley de alimentos, publicada en La Gaceta, Diario Oficial N 57 del 24 de marzo de 1992: “El derecho de alimentos es imprescriptible, irrenunciable e intransferible". 
Entonces, conviene mejor atenerse a la finalidad de la indemnización por daños morales para conjugar estos intereses que a primera vista parecen contrapuestos: la naturaleza personal y la transmisibilidad. En este orden de cosas, dice el referido jurista, GARCía LóPez (I 990), que el propósito de esta reparación es proporcionar una satisfacción al perjudicado, luego, el precio de la cesión, garantía o donación representaría para la víctima la correlativa satisfacción del daño. Significa esto que el titular del derecho puede disponerlo de la manera que estime más conveniente. Para fundamentar esta afirmación este autor pregunta “¿Acaso si la víctima ejercita personalmente la acción y obtiene la indemnización pecuniaria, y posteriormente satisface con ella, por ejemplo, una deuda pendiente, no lo hace con el precio de sus sentimientos? (pp. 195-196).

\section{A igual conclusión llega la profesora chilena Domínguez Hidalgo (200ob), para esta catedrática}

... la inconsistencia de admitir la transmisibilidad de la acción a los herederos, pero negar su cesión a terceros es evidente (...) si se admite la reparación económica del daño moral, habrá de aceptarla en todas sus consecuencias y no darle un carácter patrimonial para algunos casos y negarlo para otros (p. 733) ${ }^{54}$.

No se comparte esta opinión; en el caso de los acreedores, ya se ha señalado que de conformidad al artículo art. 1870 C (equivalente al art. 1111 CC de España), ellos solo pueden ejercitar los derechos y acciones del deudor que no sean inherentes a su persona. Es decir, no pueden ejercer la acción subrogatoria cuando se trata de derechos personalísimos. El sentido del término "ejercitar" que mejor se amolda al espíritu de este precepto es el de "hacer uso de un derecho, capacidad o virtud” (Diccionario RAE, 2001, p. 868) ${ }^{55}$. Resulta claro que si no puede hacer

54 Tal vez esta prestigiosa jurista no toma en consideración que, como se ha dicho, una importante finalidad que se persigue cuando se admite la transmisión del daño moral, es evitar que el daño causado a la víctima mortal quede sin la debida reparación. Y, precisamente, no se puede reparar el daño moral cediendo la acción a un tercero o adjudicándola a un acreedor.

55 Para el maestro ALBALADEJO (2002, p. 224), la expresión inherentes a la persona no es del todo precisa y debe entenderse por ella "... a los poderes no patrimoniales y a los patrimoniales que requieren una apreciación personalísima (por ejemplo, revocar una donación por ingratitud de donatario)”. De acuerdo con la STS, 1a , de 26-04-1962 (Ponente: Francisco Bonet Ramón, RAJ 1962/1709), se conceptúa los derechos inherentes a la persona del deudor, como los derechos personalísimos. Según el criterio del tratadista DE ÁNGEL YAGÜEZ (1993), las palabras “exceptuando las que sean inherentes a su persona", del citado precepto, suscitan dudas sobre la posibilidad de que el acreedor reclame indemnización por daños morales causados a la víctima, su deudor. (p. 891). La sentencia relacionada se refiere a una demanda sobre nulidad de contrato de liquidación de sociedad legal de gananciales y otros extremos con ocasión a desavenencias conyugales que habían concretado los excónyuges, la parte demandante ejerció la acción subrogatoria con el argumento de la inexistencia o simulación de 
uso del derecho a la reparación del daño moral, por ser este un derecho inherente a la persona del perjudicado, no tiene sentido que se le pueda transferir un derecho que la ley le impide ejercitar. Tampoco se cree que sea pertinente admitir la cesión, donación o garantía de este derecho en virtud de una interpretación y aplicación analógica del citado artículo. De verdad, un simple análisis racional indica que no tendría sentido prohibir el ejercicio de este derecho los acreedores y concurrentemente permitírselo a cualquier tercero. Hay que tener presente que se está ante un derecho con un contenido muy peculiar que se deriva de la transformación de un interés no pecuniario en un derecho patrimonial, y esta característica hace que la transmisibilidad de este derecho sea bastante atenuada y quede restringida a los herederos y perjudicados del de cujus.

Permitir la transmisión indiscriminada del crédito proveniente del derecho a la reparación del perjuicio moral significa mercantilizar los sufrimientos ¿ No repugna a la idea de justicia que la reparación del sufrimiento causado al honor de una persona famosa pueda terminar siendo subastada?. Es cierto que este ejemplo imaginario muy pocas probabilidades tiene de materializarse en el orbe de la realidad, pero es que el mismo jurista García López (ı 990, p. 197) admite que "en el mundo de lo práctico ningún acreedor hipotecario aceptaría que se le transmitiese el derecho a la indemnización de los daños morales de su deudor", sobre todo, si se toma cuenta que en muchas situaciones es muy difícil predecir a cuánto ascenderá el monto de la reparación, especialmente cuando se trata de atentados al honor, reputación, intimidad o buen nombre de las personas. Resulta más práctico esperar que el damnificado cobre la respectiva indemnización y después haga con el dinero el uso que estime más conveniente para procurarse satisfacciones. Es decir, si al perjudicado le satisface utilizar este quatum indemnizatorio para pagar una deuda, cancelar una hipoteca o hacer una donación, nada impide que lo utilice para estos fines. Pero esto es diferente a permitir que cualquier persona ocupe el lugar de la víctima en virtud de una transmisión inter vivos y ejerza las respectivas acciones indemnizatoria para quejarse por un dolor moral padecido por otro y que no le ha causado ningún malestar.

la liquidación referida, los tribunales de instancia y el TS desestimaron la pretensión por inexistencia de la nulidad accionada. Consultar también la sentencia en Jurisprudencia civil (1962), t. 108, abril, pp. 700-712. 


\section{Conclusiones}

1. La transmisibilidad de la acción de reparación del daño moral tiene como finalidad evitar que este rubro de daños (causado a la víctima inicial) quede sin compensación, y nadie mejor que los herederos y perjudicados por el deceso de la víctima para certificar, como continuadores de su personalidad del causante, que esta compensación sea debidamente satisfecha.

2. Existe una controversia doctrinal y jurisprudencial con respecto a determinar si las personas que pueden reclamar la indemnización por las lesiones o muerte del perjudicado directo están legitimadas iure hereditario, es decir, por ser los herederos de la víctima, y/o iure proprio, o sea, por ser los perjudicados directos por la muerte del interfecto.

3. Adscribirse a la vía iure hereditario beneficia de manera global a los herederos o familiares del extinto, sin precisar qué cuantía le corresponde a cada uno. Este comportamiento probablemente obedezca a razones de facilidad para jueces y fiscales, pues de lo contrario, admitir la legitimación iure proprio significa tener que investigar individualizadamente quiénes son y qué porcentaje de la reparación corresponde a cada uno de los afectados.

4. En las jurisprudencia civil española, luego de un antagonismo de las salas civiles y penales, finalmente se ha impuesto un criterio a favor de la legitimación iure proprio de los perjudicados.

5. Desligar el concepto de reparación del concepto de herederos, en caso de muerte, amplía el panorama de los sujetos beneficiarios de la indemnización, abarcando a todos los perjudicados sean herederos o no, siempre que demuestren el pesar o desconsuelo, porque con el fallecimiento del occiso se rompen los lazos de convivencia y afecto.

6. Así como del nasciturus, si nace con vida, sus derechos se retrotraen al momento de su concepción, de igual manera, al consumarse la muerte de la víctima, el nacimiento de su derecho de indemnización por daños morales se retrotrae al momento en que se produce el acto que posteriormente provocó el desenlace fatal. Por lo tanto, este derecho ingresa a su patrimonio y es perfectamente transferible.

7. La mayor parte de la doctrina, incluyendo el sector renuente a concebir la transmisión hereditaria de la acción de reparación en casos de muerte instantánea, admite la transmisión de esta acción, cuando el fallecimiento no se produce de forma inmediata. Sin embargo, de forma paradójica, esto juega en contra de esta línea doctrinaria reacia a la legitimación iure hereditaria; pues, el carácter instantáneo o no de la muerte, es una diferencia accidental que no justifica un diverso régimen jurídico. 
8. Resulta chocante a la idea de justicia que mientras cualquier mínima lesión sea objeto de indemnización, el atentado al más excelso de los bienes que un ser humano posee (la propia vida) pueda quedar sin compensación, por elucubraciones tan artificiosas como la simultaneidad o no entre el accidente y el deceso del interfecto.

9. Propugnar que la reparación del daño extrapatrimonial solo puede ser transmitida a los sucesores de la víctima inicial, si éste había deducido la acción de indemnización antes de su fallecimiento, es tan absurdo como admitir que el derecho nace de la acción, cuando en realidad, la acción surge del derecho.

10. La muerte en sí, no origina la responsabilidad, sino el acto que desencadena el desenlace fatal. Este acto, obviamente, es anterior a la muerte del interfecto y por eso entra a su caudal hereditario y es transmitido a sus herederos.

11. Los familiares cercanos a la víctima mortal, unidos a este último por sólidos vínculos afectivos, pueden estar legitimados para reclamar una indemnización tanto por derecho propio como en su cualidad de heredero; es decir, ambas posturas doctrinales no tienen necesariamente que excluirse entre sí.

12. La escogencia de la vía iure hereditatis u optar por la doctrina del iure proprio no constituye una discusión bizantina, sino que, por el contrario, produce importantes consecuencias prácticas.

13. La doble titulación, mediante la cual los herederos y/o perjudicados pueden accionar en virtud del iure proprio y el iure hereditatis, es la más acorde al principio pro damnato, que establece una interpretación de las normas de la responsabilidad civil en el sentido que sea más favorable al perjudicado o víctima del daño.

14. Cuando esta doble titulación (herederos y perjudicados) coincida en las mismas personas, se deben demostrar ambas cualidades para poder beneficiarse de las partidas indemnizatorias. Es decir, no basta ser familiar (heredero) del interfecto para tener derecho a recibir la transmisión del derecho a la reparación del daño moral padecido por él, sino que es necesario que demuestre su calidad de perjudicado. De esta manera se impide que los familiares lejanos o, los que siendo cercanos, no mantuvieran ningún vínculo con la víctima mortal o, incluso, acreedores o el mismo Estado, puedan percibir la reparación del daño moral padecido por el causante.

15. Consideramos que la transmisibilidad de la acción de reparación del daño moral tiene un carácter restringido, porque se está ante un derecho con un contenido muy peculiar que se deriva de la transformación de un interés no pecuniario en un derecho patrimonial, y esta característica hace que la transmisibilidad de este derecho sea bastante atenuada y quede restringida a los herederos y perjudicados por la muerte del de cujus. 
16. Admitir la transmisión del Derecho a la indemnización por daños morales que ocasionen la muerte a acreedores de la víctima o permitir su cesión por actos inter vivos, desvirtúa la función compensatoria satisfactoria que se le atribuye a esta clase de daños.

\section{Referencias bibliográficas}

Albaladejo, M. (2002). Derecho civil, t. 2. Derecho de obligaciones. (11a. ed.). Ed. Rev. por F. Reglero. Barcelona: Bosch.

Alonso Prieto, L. (1972). Indemnización por causa de muerte: composición del proceso civil en el supuesto de pluralidad de perjudicados. Revista de Derecho de la circulación, ( no 5, septiembre-octubre), pp. 429-436.

Álvarez Vigaray, R. (1966). La responsabilidad por daño mora. Anuario de Derecho civil, (enero-marzo), pp. 81-116.

Antón Oneca, J. \& Rodríguez Muñoz, J. A. (1949). Derecho penal. Parte general, t. 1, Madrid: Gráfica administrativa,

Bercovitz y Rodríguez-Cano, R. (1976). Derecho de la persona. Madrid: Montecorvo, S.A.

De Ángel Yagüez, R. (1993). Tratado de responsabilidad civil.(3a.ed.). Madrid: Civitas.

De Castro y Bravo, F. (1956). La indemnización en caso de muerte (Estudio en torno .a la jurisprudencia del Tribunal supremo). Anuario de Derecho civil, (abril-junio), pp. 449-504.

De Cupis, A. (1975). El daño. Teoría general de la responsabilidad civil. (trad. 2a . ed por Á. Martínez Sarrión.). Barcelona: Bosch.

Demogue, R. (1924). Traité des obligations, t. IV: Sources des obligations. Paris: Librairie Arthur Rousseau.

DíEz-Picazo, L. (1973). Estudios sobre la Jurisprudencia civil. (vol. 1). (2a ed.). Madrid: Técnos.

Díez-Picazo, L. (1993). Fundamentos de Derecho civil patrimonial. (vol. 2). Las relaciones obligatorias. (4a. ed.). Madrid: Civitas.

Díez-Picazo, L. y Gullón, A. (2002). Sistema de Derecho civil, vol. 2: El contrato en general. La relación obligatoria. Contratos en especial. Cuasicontratos. Enriquecimiento sin causa. Responsabilidad extracontractual. (2a . reimpresión de la 9a ed.). Madrid: Tecnos.

Domínguez Hidalgo, C. (2000ª). El daño moral. (t. 1). Santiago: Editorial jurídica de Chile.

Domínguez Hidalgo, C. (2000b). El daño moral. (t. 2). Santiago: Editorial jurídica de Chile.

García Hirschfeld, J. L. ( 1979). Ensayo sobre temas varios de Derecho de daños. Revista de Derecho privado, (noviembre), pp. 1026-1050.

García López, R. (1990). Responsabilidad civil por daño moral. Doctrina y jurisprudencia. Barcelona: JM Bosch editor. 
Gázquez Serrano, L. (2000). Indemnización por causa de muerte. Madrid: Dykinson.

Gómez Orbaneja, E. (1949). La acción civil del delito. Revista de Derecho privado, (marzo), pp. 185-212.

Gullón Ballesteros, A. (1972). Curso de Derecho civil. Contratos en especial. Responsabilidad extracontractual. Madrid: Tecnos.

LACruz Berdejo, J. L. (1958). Algunas consideraciones sobre el objeto de la acción subrogatoria. En J. L. Lacruz Berdejo. Estudios de Derecho civil (pp. 200-241). Barcelona: Bosch.

Lacruz Berdejo, J. L.; Sacncho Rebudilla, F. de A.; Luna Serrano, A., Delgado Echeverría, F., Rivero Hernández, F., y Rams Albesa, J. (2002). Elementos de Derecho civil, t. 2: Derecho de obligaciones, vol. 2: Contratos y cuasicontratos. Delito y cuasidelito. (2a . ed.). Revisada y puesta al día por F. Rivero HernánDEZ. Madrid: Dykinson.

Lambert-Faivre, Y. (1990). Le droit du dommage corporel. Systèmes d'indemnisation. París: Dalloz.

López Jacoiste, J. ( 1993). Reflexión sobre las indemnizaciones por causar la muerte., En Estudios de Derecho civil en homenaje al profesor Dr. José Luis Lacruz Berdejo. (Vol. 2). (pp. 1561-1580). Barcelona: J. M. Bosch.

Madridejos Sarasola, J. (1962). Los Derechos personalísimos. En A. de la E. Martínez-Radío (Dir.) Estudios de Derecho privado (pp. 159-184). Madrid: Editorial Revista de Derecho privado.

Marín López,J.J. ( 1997). Los perjudicados por la muerte en accidentes de circulación (sobre la tabla I del $<<$ Sistema para la valoración de los daños y perjuicios causados a las personas en accidentes de circulación >>). Aranzadi civil, pp. 47-77.

Martín Casal, M., Ribot, J. \& Solé, J. (2001). Non pecuniary loss under Spanish low. En W. V. H. Rogers \& H. Koziol (Coords.). Damage for non-pecuniary loss in a comparative perspective (pp. 192-243). NewYork, Viena: SpringerWien.

Martín Villa, P. \& Blanco, M. ${ }^{a}$ D. (1992). Sobre la transmisibilidad de las obligaciones <<ex cuasi delicto>>. Revista de Derecho privado, ( julio-agosto), pp. 662-665. Mazeaud, H., Mazeaud, L. y Mazeaud, J. (1978). Leçons de Droit civil, t. 2, vol. 1: Obligations: théorie genérale. ( $6^{\mathrm{a}}$. ed.). Paris: Chabas, Montchrestien.

Mazeaud, H., Mazeaud, L. y Tunc, A. (1963). Tratado teórico y práctico de la responsabilidad civil delictual y contractual, t. 2, vol. 2. (trad. de la 5a . ed. por L. AlcAlá-Zamora y Castillo). Buenos Aires: Ediciones jurídicas Europa-América.

Medina Crespo, M. ( 2000). La valoración civil del daño corporal. Bases para un tratado. Análisis jurídico del sistema incluido en la Ley 30/95. Doctrina y jurisprudencia, $t$. 4: El fallecimiento, Madrid: Dykinson.

Minozzi, A. (1909). Studio sul danno non patrimoniale (danno morale). (2a . ed.). Milano: Societá editrice libraria.

Montés Penadés, V. L. (1996). Comentario al Título V: De la responsabilidad civil derivada de los delitos y faltas y de las costas procesales. en T. A. Vives AnTón (Coord.) Comentarios al Código penal de 1995. (vol. 1). Valencia: Tirant lo Blanch, 
O’Callaghan Muñoz, X. (1987). Compendio de Derecho civil, t. 2: Derecho de Obligaciones, vol. $1^{\circ}$ Teoría General de la obligación, del contrato y del acto ilícito. Madrid: Editorial Revista de Derecho privado.

Orgaz, A. (1967). El daño resarcible (Actos ilícitos). (3a ed.). Buenos Aires: Depalma, Argentina, 1967.

Orozco Gadea, G (2006). La Unidad del daño moral. Tesis doctoral no publicada, Universidad de Salamanca, España.

Pantaleón Prieto, F. (1983). Diálogo sobre la indemnización por causa de muerte. Anuario de Derecho civil (octubre-diciembre), pp. 1567-1585.

Pantaleón Prieto, F. (1989). La indemnización por causa de muerte. Anuario de Derecho civil, (abril-junio), pp. 613-651.

Pizarro, R. D. (2000). Daño moral. Prevención. Reparación. Punición. El daño moral en las diversas ramas del Derecho. Buenos Aires: Hammurabi.

Planiol, M y Ripert, G. (1946). .Tratado práctico de Derecho civil francés, t. 6: Las obligaciones. por P. Esmein, trad. M. Díaz Cruz y E. Le Riverend Brusone. La Habana: Cultural.

Rajoy Sobredo, M. (1973). Doctrina del Tribunal Supremo sobre la titularidad del Derecho al resarcimiento por la muerte de una persona. Revista de Derecho judicial, (enero-marzo), pp. 36-61.

Ravazzoni, A. (1962). La riparazione del danno non patrimoniale. (Milano): A. Giuffrè-Editore.

Roig Torres, M. (2000). La reparación del daño causado por el delito. (Aspectos civiles y penales). Valencia: Tirant lo Blanch.

Sánchez VÁzquez, J. J. ( 1973). Derechos y acciones del perjudicado en los casos de responsabilidad civil por accidente mortal ( $1^{\mathrm{a}}$ parte). Revista de Derecho de la circulación, (enero-febrero), pp. 1-25.

Santos Briz, J. (1993). La responsabilidad civil. Derecho sustantivo y Derecho procesal. ( 7a. ed.). Madrid: Montecorvo.

Scognamiglio, R. (1957). Il danno morale (Contributo alla teoria del danno extracontrattuale). Rivista di Diritto civile, (vol. 1), pp. 277-336.

Scognamiglio, R. (1962). El daño moral. Contribución a la teoría del daño extracontractual, trad. y notas de F. Hinestrosa, Bogotá: Universidad el externado de Colombia.

Soto Nieto, F. (1970). Derecho vivo. Jurisprudencia comentada. (t. 1). Madrid: Editorial Revista de Derecho judicial.

Vattier Fuenzalida, C. (1990). Los daños familiares y terceros por la muerte o lesiones de una persona. En Centenario del Código Civil. (t. 2). (pp.2069-2086). Madrid: Asociación de profesores de Derecho civil, Centro de estudios Ramón Arce.

Vicente Domingo, E. (1994). Los daños corporales: Tipología y valoración. Barcelona: JM Bosch. 


\section{Abreviaturas}

BOE Boletín Oficial del Estado (español)

C Código civil nicaragüense

CC Código Civil español.

$\mathrm{Cp}$ Código Penal.

p. Página.

pp. Páginas.

RAJ Repertorio Aranzadi de Jurisprudencia.

RJ Repertorio de Jurisprudencia.

SAP Sentencia de la Audiencia Provincial.

STC Sentencia del Tribunal Constitucional.

STS Sentencia del tribunal Supremo.

TS Tribunal Supremo. 